\title{
Materiality, Regimes of Value, and the Politics of Craft Production, Exchange, and Consumption: A Case of Lime Plaster at Teotihuacan
}

\author{
Tatsuya Murakami \\ Department of Anthropology, Tulane University \\ 101 Dinwiddie Hall, 6823 St. Charles Ave., New Orleans, LA 70118, USA \\ E-mail: tmurakam@tulane.edu
}

\section{Introduction}

In the two decades since the publication of a review article on political economy and archaeology by Kenneth G. Hirth (1996), archaeological approaches to political economy have diversified tremendously (Smith and Schreiber, 2005; Wells, 2006). As Hirth (1996:205) states, while the original definition of political economy goes back to Marx, the redefinition of the concept within anthropology as "an analysis of social relations based on unequal access to wealth and power” (Roseberry, 1989:44 cited in Hirth, 1996:205) formed the basis for subsequent studies, which were concerned mainly with the relationship between the differential control of resources and sociopolitical complexity. These studies also expanded the scope of analysis by incorporating ideational perspectives to explore how differential access to resources was justified in terms of the Marxist concept of ideology or the Weberian notion of legitimacy (e.g., Blanton et al., 1996; Hirth, 1996:208-209). Thus, the study of ancient political economies necessarily employed top-down perspectives and developed a set of concepts and methodologies to discern various ways through which political elites controlled the production and/or exchange of resources to finance the polity (e.g., Algaze, 1993; Blanton et al., 1996; Chase-Dunn and Hall, 1997; Costin and Earle, 1989; D’Altroy and Earle, 1985; Earle, 1997, 2002; Feinman and Nicholas, 2004; Hirth, 1996; Pool and Bey, 2007; Scarborough and Clark, 2007). However, numerous studies have pointed to the importance of simultaneous formation of inequality and equality or power differentials and shared identity, which operates at multiple scales of social interaction and results from continuous negotiations among various individuals and collectivities (e.g., Campbell, 2009; Inomata, 2006; Ferguson and Mansback, 1996; Kurnick and Baron, 2016; Murakami, 2014; Schortman and Urban, 2004, 2012; Schortman et al., 2001; Small, 2009; Smith, 
2011; Yoffee, 1991). Furthermore, a series of recent studies demonstrate that corporate strategies, collective action, and cooperation, which may result in an equal access to resources, are important elements for the successful operation of polities (e.g., Blanton et al., 1996; Blanton and Fargher, 2008, 2011; Carballo, 2013; Carballo et al., 2014a; Fargher et al., 2010, 2011; Levine, 2011). In this paper, I argue that an explicit focus on consumption and its integration into the study of production and exchange are essential for understanding the formation of both inequality and equality.

While scholars have emphasized varying aspects of production and exchange, the archaeological study of consumption has mostly been restricted to festive activities (e.g., Bray, 2003; Dietler and Hayden, 2001; Wells and Davis-Salazar, 2007a) and few archaeologists have addressed consumption as a critical theoretical and methodological concept with some exceptions discussed below (see Smith and Schreiber, 2005:202-203; Wells, 2006). This is largely due to: 1) the separation of political and domestic domains, a long-held tradition in Western philosophy dating to Aristotle, in which production and exchange are conceived of as belonging to political domains and consumption to domestic domains; and 2) the historical background of the study of consumer culture within sociocultural anthropology, which is closely associated with the development of modern capitalism (Appadurai, 1986, 2005; Miller, 1987, 1995), and our assumption that such studies would illuminate little about pre-capitalist societies (see Miller, 1987; Mullins, 2011). In terms of archaeological data analysis, consumption patterns tend to remain descriptive and are treated as a given and as a reflection of social relations, which, in turn, provide insights into the study of production and exchange (e.g., Hirth, 1998). In many cases, consumption is subsumed in the concepts of production and exchange and certain consumption behaviors and their process have been assumed, rather than investigated. For example, it is often stated that "production is organized to meet the needs of consumers" (Costin, 2004:191), but how these needs are defined is left unexplained. In regard to the simultaneous formation of inequality and equality, Schortman and his colleagues (2001; see also Schortman and Urban, 2004:206-207) demonstrate that elaborately decorated ceramics with possible symbols of a polity identity were produced at the regional capital and were widely distributed to people of all ranks in the Naco Valley during the Late Classic (600-900 AD), whereas the use of elaborate masonry structures and sculptures was restricted to political elites. What is lacking in this kind of archaeological narrative, however, is the agency of consumers (but see Brumfiel, 
1987a, b; Levine, 2011; Steel, 2002, 2013; Wells, 2006). What defined the collective demand for such artifacts? What kind of value systems promoted the consumption of certain objects? Clearly, we cannot assume faceless automata who consume objects whenever they were made available through certain exchange systems, productive forces, or decisions of ruling elites. Instead, we need a theory or theories of consumption to address the actual process of how demands are created and how consumption of certain objects enhances power and identity in order to fully understand the relationship between production, exchange, and consumption (Appadurai, 2005; Miller, 1987, 1995).

In the reminder of this paper, I first discuss the broad theoretical framework of this study, which centers on the materiality of power and identity. Then, I develop and operationalize some concepts revolving around consumption, specifically the regimes of value (Appadurai, 1986), and discuss methodologies to integrate production, exchange, and consumption. To illustrate the point, I present an integrative approach to the study of lime plaster in the early urban center of Teotihuacan, which was the capital of a regional state in Central Mexico from 150 to 650 AD.

\section{Beyond Political Economy: Materiality of Power and Identity}

Political economy, as the polity finance based on unequal access to resources, forms a part of larger processes of the formation of inequality and equality. The simultaneous formation of contradictory principles, such as power differentials and shared identity, can be framed in terms of the multidimensional nature of power relations. It is now widely acknowledged that power ${ }^{1}$ should be conceptualized as multifaceted with a multiplicity of bases (e.g., Adams, 1977; Lenski, 1966; Mann, 1986; McGuire, 1983; Paynter and McGuire, 1991; Yoffee, 2005), and that different kinds of material culture (e.g., houses and mortuary offerings) do not necessarily constitute a single consistent axis of social relations (e.g., Carballo, 2009; Hirth, 1993; Kamp, 1993; Lesure and Blake, 2002). Thus, power differentials and equality may be enhanced along various dimensions. However, these different dimensions of power should not be reified as discrete entities because these bases of power are often overlapping and intersecting (Ehrenreich

\footnotetext{
${ }^{1}$ In this paper I use the term power interchangeably with power relations which refers to the power exercised in the context of social interaction (or "power over" defined by Wolf [1990]), but the discussion of multidimensionality applies to different conceptions of power, including "power to" (or agentive power) and "power through" or diffused power (e.g., disciplinary power defined by Foucault) (see Giddens, 1979; Mann, 1986; Wolf, 1990).
} 
et al., 1995; see also Sewell, 1992:19). For example, public spectacles in complex societies may entail some transcendent power of ruling elites at the same time as they enhance shared identity through bodily experience of unity and sameness (Inomata, 2006; Murakami, 2014). Furthermore, the analytical separation of despotic and infrastructural power also entails multiple dimensions of power, the latter being defined as the state's ability to penetrate into civil life through its own infrastructure (Mann, 1984). Infrastructural power not only represents the ability of a polity, but also the power of the populace to influence the central decision-making processes. Implications of infrastructural power, specifically regarding how the actions and decisions of the state and its subjects are articulated with each other, have been extensively discussed in terms of collective action and cooperation, which points to the importance of the provisioning of public goods and services by the polity among others (e.g., Blanton and Fargher, 2008, 2011; Carballo, 2013; Carballo et al., 2014a; Fargher et al., 2010, 2011).

An integration of post-structuralist theories, practice theories in particular (e.g., Bourdieu, 1977, 1990; Giddens, 1979, 1984; Ortner, 1984; Sahlins, 1981), in archaeological discourse further enhanced our understanding of the heterogeneous and contradictory nature of power relations by emphasizing that social relations are reproduced and transformed as a consequence of historically contingent negotiations among multiple individuals and groups with varying interests and practical capacities (e.g., Barber and Joyce, 2007; Brumfiel, 1992; Brumfiel and Fox, 1994; Hutson, 2010; Janusek, 2004; Joyce and Weller, 2007; Levine, 2011; Lohse and Valdez, 2004; Stein, 1998; see also Scott, 1990). These studies have contributed to the conceptual and methodological advancement in archaeological practice and provide a fertile ground on which to explore how contradictory actions, principles, and strategies are mutually entangled and result in the successful operation and failure of early complex societies. The current study follows the threads of these thoughts.

An important ramification of the integration of practice theories in archaeology is an explicit recognition that a material object is both a medium and a consequence of practice (e.g., DeMarrais et al., 1996, 2004; Halperin and Foias, 2010; Hendon, 2000, 2005; Hutson, 2010; Smith, 2011). This can clearly be seen in Giddens' concept of structure, which is defined as sets of mutually sustaining rules and resources (Giddens, 1979:104). Consequently, material culture, as a constituent of structure, both enables and constrains certain practices. Moreover, structure is conceptualized as manifold, meaning that varying structures exist "at different levels, operate in 
different modalities, and are themselves based on widely varying types and quantities of resources” (Sewell, 1992:16), which provides a theoretical basis for the multidimensionality of power. Hence, material culture is not a mere reflection of sociopolitical and economic systems, but an important constituent of social relations. In other words, power and identity are as much material as relational, and it is in this sense that I explore the materiality of power and identity. I prefer the concept of materiality instead of materialization (DeMarrais et al., 1996), which connotes the transformation of the non-material to the material. Recent materiality approach (e.g., Boivin, 2008; Chua and Elliott, 2013; DeMarrais et al., 2004; Drazin and Küchler, 2015; see also Gell, 1998; Latour, 1993, 2005) has expanded the scope of the study of the materiality of human society by focusing on the physicality of substance, which affects the process and consequence of the interaction between humans and materials. I will integrate some of the insights from these recent studies as well. The conception that renders the material constitution of power and identity leads us to explore consumption as an important element of social practice and negotiation and how consumption both affects and is affected by social reproduction and transformation.

\section{Theorizing Consumption}

Consumption is an equally complex phenomenon as production and exchange, and thus we need a suite of concepts and sound strategies to develop a better theoretical understanding of what constitutes consumption (e.g., Douglas and Isherwood, 1979; Friedman, 1994; Miller, 1987, 2001; Rutz and Orlove, 1989a). Here I define consumption as a stage or stages of a life history of material objects (Kopytoff, 1986) consisting of a physical act or a set of acts of acquisition, use, deposition, and ultimate destruction (see also Miller, 1987:190; Wilk, 2004). I focus on consumption as a relatively discrete phase and identify what informs people's decision to consume certain things. However, this is purely a methodological procedure and I do not mean that consumption is independent from production and exchange, nor am I promoting a modernist dichotomy of production and consumption (see Graeber, 2011). Consumption, production, and exchange recursively constitute one another.

Consumer behavior can be understood as a consequence of people's desires to possess or use certain items. To explain the source of desires, social scientists and philosophers have developed a set of concepts centered on “value” (Graeber, 2001; Steel, 2013; Papadopoulos and 
Urton, 2012a). In general terms, value can be defined as "something that mobilizes the desires of those who recognize it, and moves them to action” (Graeber, 2001:105; see also Smith, 1995). Hence, the question we need to address is how values are socially and culturally created (Steel, 2013; Papadopoulos and Urton, 2012a, 2012b). As with multiple sources of power discussed above, there are multiple processes for the genesis of values, and several different aspects of these processes have been pursued by influential schools of thoughts, which can be summarized into the following four (see Weil, 2004): one is what I will call the Production School, which views production as the source of values; the second is the Exchange School, which views object values in terms of economic values following theories of Simmel; and the third, and the least acknowledged by political economists, is the Structural Linguistic School, which defines value as "meaningful difference" (Graeber, 2001: 2); and the last is what I will call the Art School, which has focused on the creation of aesthetic values. In addition to these four kinds of values, there is another dimension that incurs consumption: use value. Used by Marx in passing (see Appadurai, 1986; Papadopoulos and Urton, 2012a), this concept was not expanded in social science, probably due to the fact that use value can be simply described as utility or functionality rather than value. I begin by considering this concept.

\section{Use Values}

Everything that we consume has some utility or functionality, which is determined by a mix of our biological and sociocultural needs. For example, all humans need some nutritional intake for biological survival, but what to eat (and how to eat) is determined by an interaction of environment and culture. Highly relativist approaches of anthropology, along with the critique of functionalism and neoclassical microeconomics (see Wilk and Cliggett, 2007), may have enhanced our hesitation to inquire and develop use values as a useful concept. While it is true that we cannot impose our Western notions of utility, functionality, comfort, efficiency, and rationality to other cultures' practices, it is equally obsolete to dismiss some potentially universal processes that influence consumption behavior (see Cowgill, 2000a). The baseline is that use values are at least partially grounded in our biology, and we need to consider our commonsensical feeling with scrutiny, although it is beyond the scope of this paper. It should be noted that production and consumption based on basic human needs have been discussed in the 
realm of subsistence economy (Johnson and Earle, 2000), but I want to point out that the distinction of subsistence and political economy should not be reified and concepts discussed below may be equally applicable to subsistence economy to varying degrees. We can define consumption for subsistence economy as being based on the relatively higher importance of use values.

\section{Production Values}

The Production School can be subdivided into Marxists and non-Marxists. Marxist scholars basically follow Marx's argument that values arise from human labor put into the production (whose idea can be traced back to Adam Smith; see Papadopoulos and Urton, 2012a:7-12). As Miller (1987:144) summarizes, contemporary Marxist scholars place much importance on production, emphasizing the role of producers, capital, or the state as the creator of desires and needs, which can be fulfilled by the development of markets (e.g., Castells, 1977; Haug, 1986; Preteceille and Terrail, 1985). Thus, "consumption is always subservient to production interests” (Miller, 1987:144). This theoretical position is adopted by several archaeologists. For example, in defining prestige technologies, Hayden (1998:11) emphasizes the use of surplus labor to create material objects. Michael Smith (1987) also adopts this position and proposes to use material objects of high labor input to discern household differentiation (see also Feinman et al., 1981, 2006; Haller et al., 2006).

The non-Marxist Production School places greater emphasis on the skills and knowledge involved in the production process as well as on the very act of production (e.g., Dobres and Hoffman, 1999; Gell, 1992; Gow, 1999; Inomata, 2001; Weiner, 1992; Wells and Davis-Salazar, 2007a). For example, Inomata’s (2001) study demonstrates that Classic Maya elite craft producers employed esoteric knowledge and a set of skills, and the act of producing enhanced the value of objects and the status of elites (see also Hayden, 1998:11). In this view, skills and knowledge of the producer often cannot be separated from the agency of the producer, and it is critical to identify the position of the producer in a complex network of social relations (see also Costin and Wright, 1998). This kind of value is consonant with the value of an inalienable possession, discussed by Weiner (1992), which derives from its authenticity and its foundation in sacred origins (cosmological authentication in Weiner's words) (see Kovacevich and Callaghan, 
2013; Mills, 2004 for archaeological applications). Furthermore, technology of enchantment discussed by Gell (1992) constitutes an important aspect of the source of value associated with skills and knowledge (e.g., Clarke, 2012; Gosden, 2013). The symbolic value discussed by Smith (1987:322) can be accommodated as part of values derived from broadly defined knowledge. Although the term symbolic has been used to denote the religious or sacred nature of symbols (e.g., Werner and Bell, 2004), a symbol can be profane denoting just meaningful differences (Wells and Davis-Salazar, 2007b; see sign values discussed below).

\section{Exchange Values}

The Exchange School views exchange itself as the source of value. Georg Simmel (1978[1907]) defined values by the degree to which a buyer wants it and thus values arise from exchange. For him, there are no absolute values inherent in material objects; certain objects become social valuables because they are difficult to acquire, not the other way round. This notion of economic values was developed explicitly for the study of commodity exchange within modern capitalism (see also Gregory [1982] who limits the concept of value to exchange value and states that only commodities may have values, but not gifts, which are instead ranked). But by extending the definition of commodity to anything intended for exchange (Appadurai, 1986:9), the concept of exchange value has become applicable to nearly every society (see also Gregory, 1982). However, this notion of values, along with the rejection of values derived from production, leads to a circular discussion; demand emerges from how consumers recognize values, which are determined by demand. Thus, in this perspective, demand needs to be defined independently from exchange values (see below).

Within archaeology, the concept of exchange values has been implicitly applied to argue for the importance of exotic good exchange. For example, Rathje (1972) argued that consumer demands for exotic items were conducive to the rise of political elites in the Maya lowlands (see also Freidel et al., 2002). However, as Plourde (2008:383) argues, while "Admiration of and desire for prestige goods are often cited as the reasons why prestige goods' display and distribution were important in the emergence of sociopolitical hierarchy, ... the source of these desires is also often left unexplained or underspecified." One of the solutions would be to focus on the act of exchange or the value of exchange (e.g., skills and knowledge involved in 
transaction; see Helms, 1988, 1993), rather than exchange values of objects. Another solution would be to incorporate production values. Although scholars of the Exchange School (especially, Appadurai, 1986) seem to reject the importance of production values, I argue that these two different schools of thought are not mutually exclusive. Their relative importance depends on several factors, including social and physical distance between producers and consumers (e.g., Dilley, 2005; Inomata, 2001), types of objects (e.g., D’Altroy and Earle, 1985; Smith, 1987), and the nature and scale of exchange and social interaction (e.g., Smith, 1987; Thomas, 1991), among others.

\section{Sign/Symbolic Values}

The Structuralist Linguistic School conceptualizes values in a quite different way than the former two schools. While values are something measurable in both the Production and Exchange schools, in this school, values represent simply meaningful differences, in the same way that "words take on meaning only by contrast with other words in the same language" (Graeber, 2001:13). This conception of values is best exemplified by Baudrillard’s $(1981,1998)$ concept of sign-values, which represent a relation between one sign and another (see also Strathern, 1992). Social relations are materially constituted through sign values of material objects. In a similar fashion, Douglas and Isherwood (1979) highlighted the expressive and symbolic dimensions of material objects, in addition to utility and status differentiation (see also Friedman, 1994; Schneider, 1978; Papadopoulos and Urton, 2012b; Rutz and Orlove, 1989a, b). Sahlins (1976) suggests that economic value can be understood as the product of meaningful distinctions (see Graeber, 2001:14). The concept of sign values is applicable to symbolic values in the sense that symbols represent or embody meanings, including religious and sacred symbols, as some material objects may represent meaningful distinctions among supernatural entities (Werner and Bell, 2004). The concept of sign/symbolic value also accommodates the value derived from accumulated history through circulation, such as heirlooms (Lilios, 1999; see also Kovacevich and Callaghan, 2013; Flad, 2012), in that a life history of certain items incurs meaningful distinctions among items of similar kinds and hence among people who possess those items. 
The relationship between social distinctions, or identities, and material culture has been addressed by a number of archaeologists (e.g., Barber and Joyce, 2007; Brumfiel, 2000; Hendon, 2000, 2005; Lesure, 1999; Renfrew, 1986; Robb, 1999 among others; see Smith and Schreiber, 2005:202-203; Wells, 2006:278-284). For example, material culture styles have been discussed as the material reflection of social or ethnic identities (e.g., Emberling, 1999; Stark, 1999; Weissner, 1983; Wobst, 1977). Focus has been placed on the social identities and perspectives of producers (e.g., Costin and Wright, 1998; Dobres and Hoffman, 1999; Gosselain, 2000; Schortman et al., 2001; Shimada, 2007), but rarely of consumers (major exception are Barber and Joyce, 2007; Brumfiel, 1987a, b; Carballo et al., 2014b; Davis-Salazar, 2007; Flad, 2012; Lesure, 1999, 2004; Levine, 2011; Wattenmaker, 1994; Wells and Davis-Salazar, 2007b; see also Graham, 2002).

\section{Aesthetic Values}

The concept of aesthetic values is perhaps the most problematic one. The applicability of the concept of aesthetics has been extensively discussed by sociocultural anthropologists (e.g., Coote and Shelton, 1992; Gell, 1998; Ingold, 1993; Pinney and Thomas, 2001), but there is no agreement whatsoever among scholars, even as to the cross-cultural applicability of aesthetics and art as a distinct category. Several aspects of artistic value can be accommodated in the concept of production values and sign/symbolic values as art objects may be valued for their labor input, skills and knowledge associated with production, as well as semiotic and semantic aspects of those objects (e.g., Morphy, 1991; Shelton, 1992). However, there are other aspects that do not fit any of the values discussed above that may more properly be termed aesthetic. These aspects are predicated on people’s sensual response to material objects, including affective response (e.g., Roscoe, 1995), which is partially dependent on our cognitive ability. Some cognitive scientists demonstrate that there is a cognitive or neurological basis to acknowledgment and admiration of certain visual aspects of what we call artistic objects (e.g., Ramachandran, 2011). From this perspective, it is no coincidence that many ancient people were consistently drawn to certain objects, such as objects with shiny surfaces, including gold, copper, and jade (see Renfrew, 1986). While valuation is a cultural act and our vision is construed through socialization and repeated cultural practice (e.g., Goodwin, 1994), it seems important to 
acknowledge the interaction of our neural basis and cultural practice, on which our sensual response is constructed. For the lack of a better term, I use aesthetic values for those values that are predicated on people's sensual response to the material world, but which cannot adequately be expressed semiotically or semantically.

Within archaeology, the concept of aesthetic values in a broader sense (e.g., beauty) seems to have been applied rather uncritically (or in the sense of skills of artisans), and it has not played a major role in archaeological interpretation (but see Kalavrezou, 2012; Nazaroff et al., 2016; Porter, 2012). Recent archaeological exploration into the realm of senses, emotion, and affect (e.g., Skeates, 2010; Tarlow, 2012) may provide a methodological basis for understanding aesthetic values in the narrow sense. Moreover, recent materiality approach focuses specifically on the physical properties of objects (e.g., Boivin, 2008; DeMarrais et al. 2004) and provides a solid foundation for exploring the interaction between material substance, meaning, and sensual response.

\section{Entangled Value Creation and Analytical Divisions}

These five processes of value creation (i.e. use, production, exchange, sign, and aesthetic values) are an analytical construct, and the reality may be that all these sorts of values are intertwined to various degrees consciously or unconsciously into the value of objects. In other words, the value of objects consists of varying mixes of all kinds of values and consumers select certain material objects according to various degrees of understanding of socially and culturally created values, along with their interests, practical capacities, and specific situations or contexts. However, some processes of value creation may be consciously emphasized over others, and these different kinds of values may reflect emic perspectives to some extent. Here I emphasize that different kinds of values are not mutually exclusive but highlight different (and overlapping) aspects and/or stages of material objects. And they are also convertible. The translation of a type of value to another type is dependent on specific rules and social contexts in a society. For example, modern capitalism provides those rules and contexts in which use, production, sign, and aesthetic values can all be translated into exchange values. Commoditization can be understood as a process of this translation from other kinds of values to exchange value (Appadurai, 1986; Kopytoff, 1986). 
It is important to note that different kinds of values are often mutually constitutive. In fact, Appadurai (1986) combined exchange and sign values to develop a better understanding of consumption. As mentioned above, within the Exchange School, the source of desires is often left unspecified. Appadurai juxtaposed exchange and sign values (though he is not using this latter term) to explain the source of demand, thus stating that demand emerges "as a function of a variety of social practices and classifications, rather than a mysterious emanation of human needs, a mechanical response to social manipulation... or... a universal and voracious desire” (1986:29). These social classifications may take a hierarchical or a more egalitarian form (similar to indexical and canonical communication through architecture, discussed by Blanton [1994]). Thus, demand is collectively and/or politically regulated; collectively as seen in the economic egalitarianism (e.g., Gell, 1986) where collective displays of material possessions are a cultural norm; and politically as seen in the sumptuary laws in pre-modern societies (e.g., Braudel, 1981:311; Mukerji, 1983:179-182) where political elites tend to be the custodians of restricted exchange and established tastes and sumptuary customs (Appadurai, 1986:31-33; Bourdieu, 1984; Douglas, 1967; Miller, 1987:135-136; Salisbury, 1962; see also Bayly, 1986).

Although Appadurai treated social practices and classifications as a framework in which commodity exchange occurs, these social practices and classifications are embodied by the very act of exchange (and consumption), hence exchange and sign values as outlined above are mutually constitutive and simultaneously incur people's behavior in these contexts. But this does not mean that the distinction between sign values and other kinds of values is trivial. This analytical distinction has a heuristic merit for archaeology. For example, when scholars find green obsidian in a distant region from Teotihuacan, it is not clear whether the socially inscribed symbolic value of green obsidian (i.e. association between green color and cosmological meaning) was appreciated or whether sociopolitical ties with Teotihuacan was the source of status and power or both (see Spence, 1996). As Schortman and Urban (2004:192-195) state, we need to address the meaning of prestige goods (see also Bailey, 1998; Baines and Yoffee, 2000; Bayman 2002; Levine, 2011; Steel, 2013), and the analytical separation of different kinds of values contributes to this end. This is because the analytical division and consideration of different kinds of values serves to build middle-range theories (sensu Raab and Goodyear, 1984) that connect archaeological evidence to specific aspects of the materiality of power and identity. 
In other words, breaking down the value into its different aspects makes it possible for archaeologists to address each aspect separately through specific methods.

\section{Regimes of Value, Consumption, and Social Relations}

A specific combination of different kinds of values can be conceptualized as constituting a regime of value (cf. Appadurai, 1986; Greaber, 2001). The concept of regimes of value was first introduced by Appadurai (1986), but it was critiqued by Graeber (2001) for the lack of specific definition and some ambiguity. Due to his emphasis on exchange value, Appadurai's use of the regimes of value (and subsequent application by other scholars; e.g., Myers, 2001; Villarreal, 2014) tends to highlight different spheres of exchange. To better understand multiple ways in which values are created, I propose to broaden the concept and define it as a dimension along which values of objects can be compared at numerical, ordinal, or nominal scales (to use terms from statistics ). In other words, a regime of value is constituted by a set of rules for valuation, which is created, reproduced, and transformed through the entanglement of the material properties, the acts of production, exchange, and consumption, and the agency of producers, intermediaries, consumers, and other groups of people. Multiple regimes of value can exist for the valuation of different material objects (Flad, 2012). In this sense, the concept of the regimes of value converges on Giddens' concept of structure in that a structure is a mutually constitutive set of rules (schemas) and resources and there are multiple, overlapping, and intersecting structures (Sewell, 1992). This brings us back to my earlier discussion of the multidimensionality of power: power is multifaceted with multiple bases. The regimes of value are also multifaceted with multiple bases (e.g., use, production, exchange, and consumption). More importantly, the creation of values is political in nature in that it is negotiated (Flad, 2012; Graeber, 2001:115). As such, regimes of value provide an important basis for negotiating, defining, and constituting power and identity among varying social segments, including elite and non-elite populations, and at multiple scales of social interaction ranging from households to polities to interregional relations. Thus, our understanding of how material objects were valued forms an essential part of our interpretation of sociopolitical processes (Flad, 2012; Lesure, 1999). 
An explicit focus on different kinds of values also helps examine consumption as social practice that recursively constitutes social relations. For example, Veblen (1899) demonstrated that not wealth per se but the act of conspicuous consumption entailed a socioeconomic class. In a similar vein, Bourdieu (1984) attributes an active role to consumers in reproducing an elite class in France. Although framed in exchange theory, not consumption, the consumption associated with gift exchange also provides a means to gain fame, prestige, and power. Within archaeology, the consumption of exotic or prestige goods has been addressed in terms of status enhancement (e.g., Clark and Blake, 1994; Davis-Salazar, 2007). The consumption of prestige goods also has implications for early state formation as mentioned above (Freidel et al., 2002; Rathje, 1972). Within household archaeology, the consumption of social valuables provides a means to discern household differentiation (e.g., Carballo, 2009; Hirth, 1993; Lesure and Blake, 2002; Smith, 1987). It should be clear that consumption, along with production and exchange, constitutes an important aspect of social relations.

While modern economics (especially business-oriented ones) tend to treat consumers as passive (Miller, 1987:143-144; see also Douglas and Isherwood, 1979) and other social sciences (especially cultural anthropology, sociology, and cultural studies) tend to treat consumers as an active agent (see Graeber, 2011), there is no a priori reason to assume either a passive or active role of consumers. Any person is born into already existing value systems, according to which he or she is socialized. Therefore, even rulers could be passive consumers of prestige goods, unconsciously following or coerced into following pre-existing rules. Moreover, as Mullins’ (2011) review demonstrates, the study of colonial encounters (e.g., Dietler, 2005; Harrison, 2007; Scaramelli and Scaramelli, 2005; Schucany, 2005) emphasizes how local or indigenous people, who are often supposed to be passive recipients of European material culture, selectively appropriated external objects and practices and actively negotiated sociocultural transformations (see also Thomas, 1991). Thus, consumption is closely related to the reproduction and transformation of value systems, through which people negotiate social identities and power. It is clear that some aspects of production, exchange, and consumption converge in the issues of power and identity, with consumption providing another vantage point.

\section{Building an Integrative Approach to the Materiality of Power and Identity}


In order to operationalize the concept of the regimes of value and fully understand the materiality of power and identity, it is critical to build an integrative approach that binds together the material properties, the agency of multiple social actors, and the acts of production, exchange, and consumption (see Flad, 2012; Hirth, 1996; Steel, 2013). Among these, the acts of production, exchange, and consumption represent different (but continuous) stages of a life history of objects, which archaeologists have tended to pursue separately. While each stage may constitute distinct social spheres with specific groups of actors, it is important to acknowledge that these stages are mutually entangled in a complex way (Miller, 1987); each stage is both a cause and a consequence of other stages, and thus the interpretation of each stage constitutes that of other stages. The study of each stage, especially production and exchange, has produced a suite of concepts and methodologies, which shed light on different, yet overlapping aspects of social relations. This study builds on this previous work and integrates consumption as another important concept.

Production is the first stage in the life history of objects, and itself consists of several stages, including procurement, preparation, and manufacture, which may not be completed by the same individual. Production scholarship provides a vast range of variables to understand the organization of production, such as the degree of specialization, attached versus independent producers and/or production contexts, and the scale of production (e.g., Brumfiel and Earle, 1987; Costin, 1991, 2001; Costin and Wright, 1998; Inomata, 2001; Sinopoli, 1988; see Table 1 in Schortman and Urban, 2004). All these variables are closely associated with how finished products are subsequently distributed and consumed.

For exchange systems, there are numerous concepts and approaches, including Polanyi's (1944) typology of reciprocity, redistribution, and market exchange (e.g., Earle, 1997, 2002), the gift-commodity dichotomy (e.g., Godelier, 1999; Gregory, 1982; Mauss, 2000; Spence, 1996; Thomas, 1991; see also Ossa, 2013), the distinction of tax, tribute, and trade in state societies (e.g., Brumfiel, 1991; Masson, 2002: 6-7; O’Brien, 1991; see also Brumfiel and Fox, 1994; Claessen and van de Velde, 1991) and the distinction between internal and external revenues (Levi, 1988). An important implication of previous studies is that any mode or sphere of exchange does not exist in isolation, but multiple modes or spheres of exchange may coexist and complement one another. For example, exchange of luxury items may facilitate the exchange of more essential commodities (Berdan, 1980; Brumfiel, 1980, 1983; Masson, 2002). From an 
object-centered perspective, this means that the same objects can move in and out of different spheres of exchange (e.g., Bohannan, 1959) or gift and commodity circulation (e.g., Appadurai, 1986; Kopytoff, 1986). Certain materials may even become inalienable, thus excluded from exchange spheres (Davis-Salazar, 2007; Weiner, 1992). This implies that the same material objects may embody various social relations at different points in their life.

Studies of production and exchange usually start from distributional analysis of artifacts or the identification of who consumed what and where, which, in turn, provides insights into the organization of production and exchange systems. We need to connect these back to consumption. As discussed above, only a handful of archaeologists have addressed consumption in its own right with exceptions in the study of festive activities (Smith and Schreiber, 2005:202203; Wells, 2006; Wells and Davis-Salazar, 2007a) and within historical archaeology (Mullins, 2011). But some studies of household economy and non-elite populations explore consumption behaviors based on a consideration of material values to various degrees (e.g., Barber and Joyce, 2007; Carballo et al., 2014b; Hutson, 2010; Levine, 2011; Lohse and Valdes, 2004; Smith, 1987; Wattenmaker, 1994). Since all social segments consume material objects, we need to expand the scope of the analysis to include both elites and non-elite populations (e.g., Brumfiel, 1987a, 1987b; Halperin and Foias, 2010; Lesure, 1999; Steel, 2013).

In order to reconnect production and exchange to consumption, we need to explore the process of the creation and transformation of the regimes of value, which then allows for inferences about demand or the agency of consumers. As I discussed above, a viable analytical strategy would be to address each kind of value through different, yet overlapping sets of concepts and approaches and reassemble the multiple kinds of value to explore the regimes of value. For example, an analysis of production process may address production values whereas distributional analysis provides an empirical basis to examine sign and exchange values; a consideration of material properties would be indispensable for making an inference on use and aesthetic values. In this process, it is critical to identify major social actors (be they specific individuals or collectivities) and their interrelationships, which allows us to explore the entanglement of multiple agencies (Murakami, 2010). I contend that this analytical strategy constitutes the basis for interpreting political economies and the materiality of power and identity.

Perhaps not surprisingly, most of the approaches and interpretive frameworks for production and exchange studies are based on a rather limited suite of archaeological evidence, 
which can be summarized into 1) distribution and contexts, 2) direct evidence of production, and 3) material objects themselves (physical and symbolic properties). An integration of all three kinds of evidence is essential not only for the study of political economy, but also for a more nuanced interpretation of the materiality of social relations (Brumfiel and Earle, 1998; Hirth, 1998; Schortman and Urban, 2004). Finally, the fact that values are socially and culturally created and, therefore, those values are also a historical construct should be emphasized. As such, a diachronic perspective is essential for it provides context to our interpretation. In the remaining part of this paper, I demonstrate how the concepts and approaches outlined in this paper and other studies can be put into practice using lime plaster at Teotihuacan as a case study.

\section{Background: Urban Transformations at Teotihuacan}

Teotihuacan became an urban center during the Patlachique phase (ca. 150 BC to 1 AD; see Figure 1) with an estimated population of 20-40,000 people. Toward the end of the Tzacualli phase (ca. 1-150 AD) or the beginning of the Miccaotli phase (ca. 150-250 AD), it was established as the capital of a regional state in Central Mexico (Figure 2) with an estimated population of 60-80,000 (Cowgill, 2000b, 2015; Millon, 1981). Population increase in these early phases is likely due to migration from adjacent areas and other parts of Central Mexico and beyond (Sanders et al. 1979), resulting in the formation of a multi-ethnic urban center.

Large-scale monumental construction programs were carried out at this time. Early versions of the Moon and Sun Pyramids and the Ciudadela, including the Feathered Serpent Pyramid, were built along the Street of the Dead (Figure 3), and rebuilt and enlarged in subsequent phases (Murakami, 2015). A number of sacrificial burials accompanying the monumental construction attest to the strong despotic power of the new state (Cowgill, 2000b, 2015; Millon, 1993; Sugiyama, 2004, 2005, 2011; Sugiyama and Cabrera, 2007).

During the Tlamimilolpa phase (са. 250-350 AD) Teotihuacan underwent an "urban renewal” (Millon, 1981) and ca. 2,300 residential apartment compounds were constructed throughout the city to accommodate the estimated 100,000 or more residents during this peak in population growth (Cowgill, 2000b). These apartment compounds were maintained and rebuilt during the subsequent Xolalpan (са. 350-550 AD) and Metepec (са. 550-650 AD) phases (Figure 3). The standardized orientation of almost all of the structures (15.5 degrees east of astronomical 
north), as well as the general grid-like layout of the city, suggests the intervention of the Teotihuacan state in urban planning and the supply of building materials (e.g., Cowgill, 2000b, 2007; Millon, 1981, 1993). The fact that the standardized orientation conforms to the central axis of the central ceremonial zone, which preceded apartment compound construction, attests to the centrality of ruling elites in urban planning (see Sugiyama, 2005). Current evidence suggests that this highly centralized rulership underwent some major changes during the Early Xolalpan phase (350-450 AD) or perhaps earlier as seen in the termination program of the Feathered Serpent Pyramid (Millon, 1993; Sugiyama, 1998). It is possible that this change is associated with the development of bureaucracy (Murakami, 2010, 2014, 2016).

Major construction activities seem to have ceased within the central precinct during the Late Xolalpan phase (450-550 AD), whereas some surrounding apartment compounds were continuously rebuilt (Millon, 1988). This may indicate a decline of state power and/or further changes in political organization. Several architectural complexes within the central precinct were rebuilt during the Metepec phase (ca. 550-650 AD), including the Palace of the Sun and the Ciudadela, but major pyramids were never rebuilt. The absolute date for the fiery destruction of the central precinct remains controversial, but it seems clear that it occurred sometime during the Metepec phase (López Luján et al., 2006).

\section{Changing Distribution of Lime Plaster at Teotihuacan}

Lime plaster was a common architectural element at Teotihuacan, used to coat the surfaces of floors, walls, and roofs. It is a waterproof material and is antiseptic (Boynton, 1980:217). It provides a white background for mural painting and luminosity when burnished. In comparison with other architectural materials, particularly clay, its high use values and perhaps aesthetic values are pronounced and would have been acknowledged by various groups of people (see Clarke, 2012). Lime production requires a substantially higher labor input and a more complex set of skills and knowledge than clay products (daub, adobe bricks, clay coat), which speaks to high production values. These material properties, which are predicated on relatively high use, aesthetic, and production values, likely provided an arena in which various social groups negotiated power and identity. 
Lime plaster technology was probably introduced from the Puebla-Tlaxcala region to Teotihuacan toward the end of the Tzacualli or the beginning of the Miccaotli phases (Murakami, 2013). In the Puebla-Tlaxcala region, lime plaster along with talud-tablero style (a combination of sloping walls and vertical panels) is reported from the Formative site of Tlalancaleca (García Cook, 1981). Recent research at Tlalancaleca (Kabata and Murakami, 2013, 2014) suggests that lime plaster was restricted to civic-ceremonial structures, while most residential structures were made of wattle and daub (Murakami, 2013). No lime plaster is reported from the contemporaneous village site of Tetimpa (Plunket and Urunuela, 1998), where talud-tablero made of clay was used for residential structures. Thus, lime plaster was likely part of elite material culture in the Formative Puebla-Tlaxcala region, and this was probably the case for early Teotihuacan. The first extensive use of lime plaster is reported from elite residential structures at the Pre-Ciudadela (i.e., prior to the construction of the Ciudadela), which are dated to the Late Tzacualli to Miccaotli phases (Gazzola, 2009), as well as from the Moon Pyramid Building 4 and the Sun Pyramid, both of which are probably dated to the Miccaotli phase (see Murakami, 2010, 2013, 2015). Although most structures in this period were razed later and there is no direct evidence from residential structures outside the central precinct, excavations at Tlachinolpan (Blucher, 1971), a complex of Patlachique and Tzacualli phase public structures in the northwestern periphery of the city, revealed no lime plaster. Excavations at the Plaza One revealed earthen floors with no lime plaster, which are dated to the Tzacualli phase (Millon and Bennyhoff, 1961).

During the Early Tlamimilolpa phase (ca. A.D. 250-300), lime plaster was extensively used for nearly all the structures within the central precinct and at some apartment compounds. There are only a handful of excavated apartment compounds that were founded in the Early Tlamimilolpa, which include several in the La Ventilla district (La Ventilla I, II, A, and B; see Gómez, 2000; Rattray, 1997), Tlajinga 33 (Widmer, 1987), and possibly some compounds in the Oaxaca barrio (Croissier, 2007; Spence, 1992). It is likely that only privileged people had access to lime plaster. The La Ventilla district is located just west of the Great Compound (Figure 3), and it is possible that residents in the district were closely affiliated with governmental institutions (see Gómez, 2000). In fact, a burial with greenstone ornaments has been uncovered from one of these early compounds. The residents at Tlajinga 33, a lower status compound in the southern periphery of the city, did not use lime plaster. Widmer (1987; Widmer and Storey, 
1993:102) noted poor execution of structures along with its disconformity of orientation. Construction materials and techniques are different from those of compounds in the urban core, which may suggest that residents at Tlajinga 33 emulated the new style of living (Murakami, 2010, 2013, 2016). Thus, although data are scant, lime plaster was still part of elite material culture in the initial stage of urban renewal.

The majority of excavated compounds were founded during the subsequent Late Tlamimilolpa and Xolalpan phases, and lime plaster was extensively used for these compounds (Figure 4), including those of lower status residents such as La Ventilla III and Oztoyahualco 15B (Manzanilla, 1993a, b), although some households did not have access to lime plaster at La Ventilla III (Gomez, 2000). Residents at Tlajinga 33 started using lime plaster during the Late Xolalpan phase, which may indicate status change and improved living conditions. Thus, generally speaking, lime plaster was widely accessible to urban residents from the Late Tlamimilolpa phase onward. There seem to have been no major changes in the use of lime plaster until the decline of the Teotihuacan state.

\section{Direct Evidence of Lime and Lime Plaster Production}

Lime plaster production consists of several steps: procurement of raw material, burning of limestone to make lime, preparation of aggregate, slaking lime, mixing of slaked lime and aggregates, and application to walls and floors (Hansen, 2000; Schreiner, 2002). These various steps do not have to be completed by the same individual. These production steps can be grouped into two major steps: production of lime, including the procurement and processing of raw materials, and the production of lime plaster, which consists of the final plaster preparation and application. At Teotihuacan, there is little direct evidence for lime plaster production, but there are several lines of indirect evidence to suggest lime and lime plaster production.

The Teotihuacan Valley is of volcanic origin and there are no limestone sources within the valley. Thus, lime or limestone had to be imported from distant source areas. Current evidence suggests that lime production was carried out in the limestone source area and the finished product, instead of raw limestone, was imported to Teotihuacan. Lime production requires a huge amount of firewood (Barba and Córdova, 1999), but analysis of sediments in the lower Teotihuacan Valley by Córdova (1995) indicates that there was no abnormal sedimentation 
attributable to erosion, which would have been caused by deforestation. This suggests that the scale of forest exploitation was not significant within the Teotihuacan Valley. Based on this evidence along with the estimation of wood used for firewood, construction, and the production of lime at Teotihuacan, Barba and Córdova (1999:176, 2010) argue that the major sources of wood should have been outside of the valley. This strongly suggests that limestone was burnt outside of the valley, most likely in the source area, although we cannot discard the possibility that both limestone and firewood were imported to Teotihuacan until we find the evidence for lime kilns. But ethnohistoric data also suggest that lime was produced in the source area. Possible source areas of limestone in Central Mexico are a broad area extending from the northwestern Basin of Mexico to the Tula region, the Tepeaca area in Puebla, and the northern part of Morelos. During the Postclassic period, the Tula region and Tepeaca paid a regular tribute or tax of lime, not limestone, to the Aztec Triple Alliance (López Luján et al., 2003). The Zumpango region (northwestern Basin) also specialized in lime production (Blanton, 1996:Fig. 3-2).

Barba et al. (2009) conducted a provenance study of lime based on its geochemical composition and compared limestone samples from three regions (the northwestern Basin was not included) as well as lime plaster samples from the Teopancazco apartment compound. The results show that the Tula region was likely the source of lime for plaster at Teopancazco. There are numerous Teotihuacan period occupations in the Tula region, suggesting possible colonization by Teotihuacanos (Mastache et al., 2002:52), which may have engaged in lime production. The site of Chingú (Figure 2) was probably a secondary center of the Teotihuacan state (Díaz, 1980; Mastache et al., 2002:52-55), and it is likely that the supply of lime was administered by local Chingú elites. The overland distance from Teotihuacan to Chingú is about $60 \mathrm{~km}$. In addition to the Tula region, the Zumpango region is also a candidate for a lime production area during the Classic period (Carballo, 2013b; Murakami, 2010). Parsons and Gorenflo (2008:72) indicate that there was an explosive expansion of settlements throughout the Zumpango region after the Tzacualli phase. This expansion might be related to the increased demand for lime by the city residents, but this should be examined through further provenance study of lime and further archaeological research in the Zumpango region (Parsons and Gorenflo, 2008:102). The distance from Teotihuacan to the Zumpango region is about $35 \mathrm{~km}$, almost half of the distance to the Tula region. Although it is possible that lime from other source areas (i.e., 
Tepeaca and Morelos) was used for different structures and/or in different phases, I consider both the Tula and Zumpango regions as major source areas of lime based on their proximity to Teotihuacan and settlement history (Carballo, 2013b).

In regard to lime plaster production, construction projects are the loci of production and we cannot expect to find localized workshops like those for the production of portable objects. The available evidence for production at Teotihuacan includes possible tools for lime plaster application called plaster smoothers (see Cowgill, 2015:Fig. 7.14) and trowel-like tools (Magaloni, 1996:Fig. 49). These tools are ubiquitous among excavated apartment compounds (e.g., Linné, 1934, 1942; Manzanilla, 1993a; Séjourné, 1966), but their density per square meter varies greatly from 0.01 at Tlamimilolpa to 0.19 at Tetitla (Manzanilla, 1993a:557). Moreover, 40 plaster smoothers were recovered from a burial at La Ventilla (Piña Chan, 1963:52), which might indicate this individual's status as a producer of plaster smoothers and/or a plasterer. At the Oztoyahualco 15B apartment compound, a pile of lime along with a plaster smoother was recovered next to a burial pit in a room dated to the Xolalpan phase (Manzanilla, 1993b:168). Manzanilla (1993a:557) states that the apartment was abandoned before the burial pit was sealed with lime plaster. This shows a clear evidence that some residents of Oztoyahualco 15B engaged in lime plaster production. In any case, this evidence suggests that some residents participated in lime plaster application within their own compounds and some others probably worked beyond their own compounds, perhaps specializing in this task (Lizárraga and Ortiz Butrón, 1993). These residents probably worked under master plasterers (see below).

\section{Material Characterization of Lime Plaster at Teotihuacan}

\section{Quality and Recipe of Lime Plaster}

The physical characterization of objects forms an essential part of the study of production organization. In this study, I characterize plaster by focusing on two intersecting aspects of compositional variability: quality and recipe. Since better-quality lime plaster requires higher labor inputs (Hansen, 2000; Spensley, 2004), qualitative difference can be equated with differential access to labor and be used as a measure of power differentials, which have implications for production organization. Given that lime plaster was "experienced" on a daily 
basis, it is likely that the quality of lime plaster was a major concern for the residents in practical and aesthetic terms (see Clarke, 2012) and thus was likely prone to technological changes. Moreover, quality differences suggest that lime plaster production was organized by differing socioeconomic sectors. Conversely, no variability in quality indicates strong control of production. Lime is not locally available in the Teotihuacan Valley as mentioned above and is likely to reflect differential consumption between different social segments if there is no central control (see Spensley, 2004).

The assessment of recipes serves to examine the organization of lime plaster production. The existence of multiple recipes indicates that there were multiple learning communities (Wenger, 1998; see Abrams, 1996), which were not necessarily under centralized control. A single recipe throughout the city implies centralized control or administration of plaster production. It is unlikely that a number of different producers happened to share the same recipe if there is no control marked by centralization and standardization of production practice. Lime plaster is a plastic material and its composition can be changed easily. Such a material property provides a number of technical choices for producers, and standardization is likely achieved through some kind of control. In fact, it is reported that there is great variability in recipe at a relatively small site in the Maya area (Spensley, 2004) and even within a single structure (Morris et al., 1931).

The quality and recipe of lime plasters can be studied independently from each other and thus they provide two axes of comparison (socioeconomic difference and centralization). This produces four possible combinations, each of which has different implications. However, it should be noted that quality and recipe might be closely interrelated. Different recipes may be selected for making plasters of better quality. Because quality can be defined both aesthetically and functionally, its interpretation may be ambiguous, especially when emic criteria for qualitative difference are not known. To avoid this ambiguity, I limit the use of quality to its functional aspect.

As mentioned above, lime plaster production at Teotihuacan consisted of several steps, and thus there are different points at which technical choices in lime plaster production can become evident in the final product. In this study, I present a preliminary analysis focusing on a limited set of variables related to the quality and/or recipe of lime plaster. Specifically, I examine the degree of calcination of lime, types of aggregate, and the ratio of binder and aggregate. 


\section{The Degree of Calcination}

Lime production begins by heating raw materials containing calcium carbonate $\left(\mathrm{CaCO}_{3}\right)$ such as limestone to ca. $900{ }^{\circ} \mathrm{C}$ to drive off carbon dioxide to produce calcium oxide $(\mathrm{CaO})$ or quicklime. The quality of lime can be measured by the degree of calcination (the degree of removal of $\mathrm{CO}_{2}$ ). Good quality lime can be defined as highly calcined lime and bad quality lime as incompletely calcined lime. Well-calcined lime promotes the cohesion of the paste, resulting in harder (i.e. more durable) plaster. The degree of calcination is a function of heating temperature and to keep a higher temperature needs more and/or higher quality fuels and skills. Thus, highly calcined lime reflects more investments of material and/or human resources ${ }^{2}$.

\section{Types of Aggregate}

Since lime paste shrinks to a great extent during drying, which causes extensive cracking, a charge of mineral material or aggregate, such as sand and crushed limestone, is necessary to temper lime plaster (Hansen, 2000:70-71). Aggregate is used also to strengthen the paste. In addition, aggregate improves the cohesion of the paste and assists in the crystallization of calcium carbonate by forming ducts, which facilitate the flow of carbon dioxide during drying (Swallow and Carrington, 1995).

The use of different materials for aggregate may indicate the existence of multiple recipes of plaster making (see Abrams, 1996). At Teotihuacan, quartz, feldspar, amphibole, and limestone were mainly used for aggregate (Barba et al., 2009; Barca et al., 2013; Magaloni,

\footnotetext{
2 There are other variables that indicate diffrential quality of lime plaster, including slaking procedure, but they are often difficult to identify technically or to correalte with the quality (Schreiner, 2002; Hansen, 2000). Slaking lime forms the second step of lime production, and water is added to quicklime to create slaked lime or hydrated lime (carbon hydroxide, $\mathrm{Ca}(\mathrm{OH})_{2}$ ). This can also be achieved through “air-slaking” (e.g., Schreiner, 2002). The lime paste is usually stored for a lengthy period (up to 5 years or longer). Hansen (2000:66) mentions that this improves the quality of lime, probably due to increased conversion of quicklime to hydrated lime and other factors. If so, insufficient slaking results in poorly crystallized lime matrix. Although analytical techniques to discern variation in the slaking process and the differences in the quality of the resultant product are not well-established (e.g.,Hansen, 2000:83), the degree of the development of calcium carbonate crystals and the presence/absence of calcium oxide may be indicative of the quality of lime. It is possible that lime lumps result from insufficient mixing of quicklime and water or slaked lime paste and aggregate. Lindroos (2005:48-49) suggests that the lime partly hardens before mixing with aggregate, causing the formation of lumps in the plaster matrix. If so, the presence and amount of lime lumps may be indications of poorly handled lime paste (but see Hansen, 2000:65). In addition to slaking process, organic (plants and animal products) and inorganic (clay) additives are indicative of lime plaster quality. For example, organic additives have effects on solubility of calcium hydroxide in water (Boynton, 1980; Hansen, 2000:67-68). But these were not considered in this study.
} 
1996). Since types of aggregate changed over time (Magaloni, 1996; Magaloni et al., 1992), aggregate might have been a major concern for producers and might reveal the existence of multiple recipes across the city.

The quality of aggregate may be measured as the degree of sorting, which partially determines the plasticity or hardness of lime plaster (Spensley, 2004). Good quality aggregate can be defined as highly sorted. It requires higher labor inputs. However, Hansen (2000:71) also mentions that an aggregate that gradates (including both larger and smaller aggregate) serves to make a coherent lime matrix. In addition, the aggregate size has an important effect on the final product. Large-sized aggregate may promote cracking in the matrix between aggregate particles and fracturing around the particles, whereas smaller-sized aggregate promotes a more coherent end product (Hansen, 2000:71).

\section{Binder-Aggregate Ratio}

Aggregate may be added to the lime paste during the slaking of lime or just before its application. The proportion of aggregate to lime binder affects the overall strength of lime plaster (Hansen, 2000:71). Thus differences in the ratio of lime binder and aggregate may be indicative not only of different recipes but also of the quality of lime plaster. However, it is not straightforward to equate different ratios of binder and aggregate to the quality of lime plaster. While a certain amount of aggregate is necessary to make a good-quality lime plaster, aggregate may also be used to expand the paste especially when access to lime is limited (Hansen, 2000; Spensley, 2004). Due to the lack of a one-to-one relationship between the binder-aggregate ratio and the quality of lime plaster, I use this variable exclusively to examine the recipe.

\section{Sample and Analytical Methods}

In total, 120 samples of lime plaster collected from 15 architectural complexes were used for this study (Table 1). The samples from the principal courtyard and those with clearer chronological information (e.g., dated through ceramic analysis) were mainly chosen. The sample identification number consists of the abbreviation of each architectural complex (e.g., Moon Pyramid = MP), followed by an F or W, for floors and walls respectively, and the consecutive number for each set of floors and walls within each architectural complex. 
I conducted cathodoluminescence (CL) and petrographic thin section analysis on all of 120 samples. CL analysis of minerals is based on visible luminescence (photons) emitted by a mineral when it is bombarded by high-energy electrons that are produced in a cathode (Marshall, 1988). These resulting emissions have distinct wavelengths and intensities derived from differences in the kinds and phases of minerals present. Its archaeological application is still limited, but the studies of archaeological lime plasters and mortars show that different carbonate phases in lime plasters and mortars emit luminescence of varying colors and intensity (Hale et al., 2003; Heinemeier et al., 1997; Lindroos, 2005; Lindroos et al., 2007; Shenwan, 2008): unburnt limestone has a strong red-orange luminescence, whereas lime binder (burnt limestone) shows a dull tile-red to brown luminescence. There are both luminescent and dull lime lumps (Lindroos, 2005:50). Incompletely burnt limestone often presents as dark red luminescence with uneven intensities (Lindroos, 2005:51). Materials other than calcium carbonate can also be differentiated through this method. For instance, quartz and feldspars have a blue/green luminescence (Lindroos, 2005).

CL analysis was conducted on thin-sections of lime plaster samples at the NSF-Arizona AMS Facility, University of Arizona. The sample was irradiated by accelerated electrons (20-25 $\mathrm{keV}$ and under $1 \mathrm{~mA}$ ) and the resultant CL images were captured through a digital camera connected to a computer. CL micrographs were then inspected to identify the composition of the plaster matrix (binder and aggregate). In this process, thin-sections were observed under a petrographic (polarizing) microscope to evaluate the results of CL analysis. For a subset of samples, I conducted an image analysis of CL and petrographic micrographs to quantify the degree of calcination and the proportion of each component (e.g., lime binder, quartz and feldspar sands), using a free program called ImageJ 1.42q (Wayne Rasband, National Institutes of Health; http://rsbweb.nih.gov/ij/index.html) (see Murakami et al., 2013 for details).

\section{Results}

Based on the stratigraphic contexts of each sample and similarities among samples from different architectural complexes, lime plasters were grouped into three major groups (Table 1). The first group is associated with the Miccaotli and Tlamimilolpa phases, and the second group is associated with the Early Xolalpan phase. These two groups appear to be relatively 
homogeneous among different architectural complexes. In contrast, the third group, which corresponds to the Late Xolalpan to Metepec phases, shows more variability in both recipe and quality, although there is no clear distinction between the central precinct and the surrounding apartment compounds.

Miccaotli to Tlamimilolpa Phases (ca. A.D. 150-350)

Lime plasters in these phases are characterized by a near absence of materials other than calcium carbonate. More than $90 \%$ (up to 99\%) of the plaster matrix consist of calcium carbonate. Occasionally, a small amount of feldspar and quartz particles are included, but they often measure only around $50 \mu \mathrm{m}(0.05 \mathrm{~mm})$. CL analysis shows that most samples contain particles that have a yellow-orange to red-orange luminescence. It was first thought that these particles are a limestone aggregate, as suggested by Magaloni (1996; Magaloni et al., 1992). However, observations by a polarizing microscope revealed that they are not unburnt limestone, suggesting that these particles are incompletely burnt limestone fragments (Figure 5). It is likely that they were incompletely calcined residues of the same burnt limestone, from which fully calcined lime was derived. It is even possible that these incompletely calcined particles were mixed unintentionally. The presence of not only medium-sized fragments but also of micronsized particles well distributed in the plaster matrix may support this interpretation. The incompletely calcined lime comprises around 5\% of the plaster matrix.

There are some variations in Group 1 lime plasters. Some samples show almost no incompletely calcined limestone fragments (the first construction stage of Complex 6:N5W1 [6GW-2], the Quetzalpapalotl Palace Complex [QPF-6, QPW-3], the West Plaza Complex [WPCF-1], and Atetelco [AtetW-5]). This implies that there were variations in the skill of lime production, but the presence of high-quality lime crosscuts the spatial division between the central precinct and apartment compounds.

\section{Early Xolalpan Phase (ca. A.D. 350-450)}

There was a drastic change in the composition of lime plaster from the previous phases, which considerably improved the quality of lime plaster. Lime plasters during the Early Xolalpan phase (Group 2) are characterized by an abundant use of volcanic ash (tephra) as a main aggregate well distributed in the well-calcined lime binder (Figure 6). The size of volcanic ash 
varies to a great extent from around $10 \mu \mathrm{m}(0.01 \mathrm{~mm})$ to nearly $1 \mathrm{~mm}$, and particles of various sizes were mixed (thus no sorting). Recent sourcing analysis suggests that volcanic ash was imported from Altotonga, Veracruz (Barca et al., 2013). Along with volcanic ash, other materials such as feldspar and quartz sands were used as an aggregate, but to a lesser extent. The proportion of binder varies from around $70 \%$ to more than $80 \%$. The amount of incompletely calcined limestone fragments decreased significantly from the previous phases, suggesting an improvement of the control on firing processes.

The change from Group 1 to Group 2 lime plasters can be clearly seen at La Ventilla II (Figure 7), the Ciudadela, and the Street of the Dead Complex. It is likely that the transition occurred at a citywide scale. As with Group 1 lime plaster, there are no identifiable differences in the quality and recipe of Group 2 lime plaster between the central precinct and the surrounding apartment compounds. Some variations are noted but are probably due to temporal changes rather than spatial ones.

Late Xolalpan to Metepec Phases (ca. A.D. 450-650)

Lime plaster samples from Late Xolalpan and Metepec contexts are grouped under Group 3, but unlike Groups 1 and 2, variations are very large among samples, and there are no definable criteria applicable to all the samples. However, there are some commonalities among most, if not all, samples. These commonalities include the following: 1) at least a small amount of volcanic ash and feldspar was used for an aggregate; 2) incompletely calcined limestone fragments are mixed up to 7\%. Some of these fragments are angular in shape and still show crystal structure of original limestone, which implies that their exposure to fire was minimum (it is even possible that unburnt fragments were mixed as an aggregate and were exposed to heat post-depositionally, such as through fiery destruction of the compound); and 3) the proportion of the binder is greater as compared to Group 2 (more than 90\%, not counting incompletely calcined limestone). It is likely that some variations are due to temporal changes. La Ventilla I provides three consecutive wall plasters from the Metepec phase, which show constant changes in their composition (Figure 8). Two superimposed layers of plaster during the final occupation of La Ventilla I (Figure 8CD) show some angular limestone fragments, which were not observed in earlier samples (Figure 8A-B). Some samples from La Ventilla II and III and the Ciudadela show similarities with one or the other sample of La Ventilla I (Murakami, 2010). Although low resolution in the 
chronological assignment of each rebuilding episode impinges on fine-grained spatial comparison of plaster composition, it is clear that the plaster composition changed several times during the Metepec phase. In addition to temporal changes, there are subtle differences which are suggestive of multiple groups of lime plaster producers during the Metepec phase. Samples from Atetelco, Zacuala Palace, and Tetitla (Figure 9) share certain characteristics with those described above, but at the same time, differ from them in other elements (e.g., the proportion, shape, and distribution of incompletely calcined limestone fragments; note that a sample from Zacuala Palace [Figure 9A-B] contains a large number of small grains of limestone or incompletely calcined limestone and a substantially reduced amount of volcanic ash). It is likely that different groups of artisans selected different raw materials and combined them in various ways. This point can be clearly seen in a floor sample from Yayahuala (Figure 10), which shows a notable difference in the size and amount of limestone or incompletely calcined limestone fragments. In summary, lime plasters during the Metepec phase are characterized by constant changes in their composition and probably by multiple groups of artisans or learning communities. However, qualitative differences crosscut the division between the central precinct and surrounding apartment compounds as in the previous phases.

\section{Summary and Discussion}

The three kinds of evidence presented above complement one another to elucidate different aspects of production, exchange, and consumption of lime plaster at Teotihuacan. Since some diachronic changes are clearly noted from the distribution and material characterization, I organize the following discussion diachronically.

\section{Teotihuacan before Urban Renewal}

During the Miccaotli phase (150-250 AD) or earlier, lime plaster technology was introduced to Teotihuacan and was used probably exclusively for monumental structures and elite residences. Given that the use of lime plaster was restricted to some monumental structures in the Formative Puebla-Tlaxcala region, coupled with close cultural connections between this region and Teotihuacan (García Cook, 1981), emergent elites at Teotihuacan likely emulated or 
participated in elite material culture, which was created during the Formative period. The nearly exclusive use of lime plaster by elites does not automatically translate to elite control of resource acquisition, production, and exchange, which needs to be examined separately from multiple lines of evidence (Graham, 2002; West, 2002). Elite control over the acquisition of raw materials and/or prestige goods is a controversial issue (e.g., Torrence, 1986; McAnany, 1991).

Ethnographic examples provided instances in which the association between elites and prestige objects is not due to control of exchange. For example, during the colonial encounters, big men in the Pacific islands obtained guns from Europeans, and these guns served as prestige goods (Thomas, 1991). Obviously, these big men were not controlling the acquisition of guns, but perhaps were controlling or regulating the demand for and access to guns in their communities. In a similar fashion, some community leaders in the Trobriand Islands acquired the most valuable Kula shells as a consequence of complex negotiations, including the creation and maintenance of social ties through gift-giving (Malinowski, 1922; Munn, 1986; Weiner, 1992). As Graham (2002:413) argues, it is more productive to examine prestige good economy in terms of elite demand, rather than elite control (see also Brumfiel, 1987a, b). This elite demand is likely constituted by a combination of different kinds of values outlined in this paper, which formed a regime of value connecting a certain object to a dimension of power relations.

As outlined above, lime plaster is a waterproof material with antiseptic properties (Boynton, 1980:217). It provides a white background for mural painting and luminosity when burnished (see Clarke, 2012). Furthermore, lime production requires a substantially higher labor input and a more complex set of skills and knowledge than clay products (daub, adobe bricks, clay coat). The relatively high use, aesthetic, and production values would have been acknowledged by elites. It is ambiguous whether lime production was administered by elites (e.g., attached specialists or some kind of patron-client relationship). At least, elite demand likely promoted intensified production and specialization of lime producers. Lime could have been obtained by Teotihuacan elites through social networks (e.g., equal or unequal alliances), trade, or tribute systems. It is difficult to discriminate between these alternative possibilities with currently available evidence, although tribute is a likely candidate considering the expansionist tendency of the early Teotihuacan state. Settlement expansion in the Zumpango and Tula region after the Tzacualli phase may have been, at least partially, associated with elite demand for lime, 
and future research in these settlements may shed light on the relationship between Teotihuacan elites and lime producers.

In contrast to lime production, lime plaster production during this phase would not require special skills and knowledge as it is almost devoid of aggregate. Lime plaster application was probably not very different from application of clay coating. In view of the restricted access to lime plaster, its distribution within the city, rather than production per se, might have been regulated in some way by elites. As noted above, the use of lime plaster likely embodied part of elite material culture or elite identity. This points to the importance of sign/symbolic values of lime plaster, which were predicated on a mix of use, production, and exchange values (see also Brumfiel, 2000). Thus, the nature of the substance (whiteness, antisepsis, and luminosity), its geological distribution (i.e., non-local), and the agency of ruling elites, along with the acts of production, exchange, and consumption created a regime of value that embodied unequal social relations.

Lime plaster as a prestige item probably continued into the Early Tlamimilolpa phase (250-300 AD), in which some intermediate elites adopted lime plaster along with the use of apartment compounds. Since these intermediate elites were closely associated with state government, there was probably no substantial change in the organization of production and exchange. Presumably, negotiation between ruling and intermediate elites resulted in the consumption of lime plaster by the latter and this probably led to the crafting of more inclusive elite identity grounded in an equal access to resources within an elite class. Thus, lime plaster likely embodied equality at this limited scale of social interaction, while remaining a material embodiment of hierarchical social distinction at a larger scale.

\section{Teotihuacan during Urban Renewal}

During the Late Tlamimilolpa (300-350 AD) and Early Xolalpan (350-450 AD) phases, lime plaster became accessible to the majority of city residents, including non-elite populations, through the urban renewal project. Material characterization shows that there were no clear differences in the quality and recipe of lime plaster among different social segments. This suggests that both the recipe and quality of lime plaster were centrally controlled by a group of artisans. The continuity of the same recipe from the Miccaotli phase to the Late Tlamimilolpa 
phase strongly suggests that production was maintained within the same group of artisans. This interpretation is corroborated by the fact that the quality and recipe of lime plaster changed at a citywide scale during the Early Xolalpan phase. The technological innovation of lime plaster that was adopted in different areas of the city, which crosscut possible barrios and districts, would result from a central control of artisans' practice. Without such control, it would result in more diversified technological practices (e.g., Hirth, 2009; Hirth et al., 2006). This centralized control of technology would be possible with a guild-like organization (e.g., Epstein, 1991). Given the wide distribution of plaster smoothers, it is clear that some residents at each apartment compound participated in lime plaster production. Compositional analysis suggests that these residents worked under master plasterers, who were in charge of quality control and were part of the guild-like organization.

Although it is difficult to specify with current evidence the exact nature of the relationship between this possible organization and the state, I am inclined to argue that the artisans were closely associated with state government for two reasons. First, lime plaster production was closely associated with ruling elites in the previous phases, and it seems reasonable to assume that this relationship continued through time, especially given the technological continuity up to the Late Tlamimilolpa phase along with the fact that a great amount of lime plaster was continuously used for structures within the central precinct. Second, the amount of lime necessary for urban renewal was substantially greater than during the previous phases (Barba and Cordova, 1999, 2010), and this would have required intensification of lime production. It seems likely that some kind of state intervention to secure the supply of lime was necessary, such as the establishment or strengthening of tribute systems through secondary administrative centers. Moreover, volcanic ash that was used as an aggregate during the Early Xolalpan phase was also a non-local resource, probably from Veracruz (Barca et al., 2013), which required further investment in its transportation. Procurement would have been facilitated or sponsored by the state, either through trade or tribute. All this strongly suggests that at least the procurement of lime and volcanic ash, and possibly the whole production process, was administered or regulated by the state.

The distribution system within the city is less clear from the current evidence, but I provide two alternative possibilities, although they are not mutually exclusive. One is redistribution or subsidies to the urban populace by the state, and the other one is open market 
exchange. If the former was the case, the amount of allocations of lime plaster likely depended on the socioeconomic status and other factors of the city residents. Lower status apartment compounds, such as La Ventilla III (Gomez, 2000), had restricted access to lime plaster, but the quality and recipe were the same. Apartment compounds are functionally diverse (e.g., Cabrera and Gomez, 2008; Gomez, 2000; Manzanilla, 2003), and it is possible that lime plaster was allocated to those apartment compounds institutionally affiliated with state government, while the rest of the populace obtained lime plaster through market exchange based on their interests and economic capacities. Market exchange in this prehispanic Mesoamerican setting is a topic that has been substantially revised recently (e.g., Garraty and Stark, 2010; Hirth, 1998; Hirth and Pillsbury, 2013). Teotihuacan may have developed market exchange organization, including a central market regulated by the state (Carballo, 2013b; Millon, 1981; Sullivan, 2006, 2007), which may have resulted in the same distribution of lime plaster.

A wider distribution of lime plaster indicates changes in the values of lime plaster, specifically its exchange and sign/symbolic values. The boundaries of the exchange sphere or presence of sumptuary laws that embodied an eliteness as well as elite/non-elite distinction through lime plaster seem to have broken down, allowing lime plaster to embody equality among the majority of urban residents at one level, and social distinction between those who have and do not have lime plaster at another level. This shift can be better understood in terms of demand. The combination of use, aesthetic, production, exchange, and sign values that were created during the previous phases likely generated desires and admiration on the part of urban residents. Miller (1987:135-136) states that, when sumptuary laws break down, emulation becomes a strategy for lower status people to enhance their position by modifying their behavior and material objects. Miller (1987:136) goes on to argue that demand "for goods may flourish in the context of ambiguity in social hierarchy." However, I would argue the contrary; demand for a variety of goods may result in the ambiguous nature of social hierarchy. While the majority of residents shared lime plaster, other kinds of material objects constituted social distinctions to varying extent, such as mural painting, room size, temple structures, and some classes of portable objects (Murakami, n.d.). Power relations are multidimensional and multi-scaler, so my discussion here should not be extended to other dimensions of power.

The suggested strong control of the production processes and administration of distribution (either through redistribution and/or market) implies a great degree of infrastructural 
power exercised by the state (Mann, 1984) and is consistent with some characteristics of a service-oriented bureaucracy (Eisenstadt, 1963:281-287) and collective states (Blanton and Fargher, 2008, 2011; Fargher et al., 2011). Bureaucracy is usually formed to implement the political goals of rulers, but at the same time it needs to meet the demands of major social groups, from which the rulers mobilize resources. Therefore, to the extent that the state relies on internal revenues (Blanton and Fargher, 2008; Levi, 1988), bureaucracy is required to provide and regulate public goods and services. It is likely that lime plaster became one such public good through a complex process of negotiations, which constituted a distinct regime of value that embodied more equal social relations and a community of practice (Wenger, 1998). This may have enhanced a shared identity among the majority of city residents.

It should be noted that strong control over the acquisition of lime by the state does not mean a state monopoly of lime. Even if lime was extracted as part of tribute, those lime producers may have distributed surplus products through social networks separate from tribute system. Hence, tribute systems may have facilitated exchange of lime in a civil sector.

\section{Last Years of Teotihuacan}

The central organization of lime plaster production and distribution likely underwent a significant change by the Metepec phase. There were no major construction activities within the central precinct and probably at many apartment compounds during the Late Xolalpan phase (Millon, 1988), which suggests that artisans could not sustain themselves to the same extent as in the previous phases, probably leading to the breakdown of a guild-like organization.

While there were continuous collective demands for lime plaster during the Metepec phase, evidence of frequent changes in plaster composition suggests that the degree of central control on the procurement of raw materials and production technology decreased significantly. The degree of calcination of lime decreased, which might be related to reduced state power in the Tula and other adjacent regions (Mastache et al., 2002:59-60; Millon, 1988). It is also likely that weakened state control coupled with the dissolution of a guild-like organization contributed to the formation of multiple groups of artisans who organized lime plaster production and distribution more or less independently from each other. There is a possibility that each apartment compound or a group of compounds organized the acquisition of some of the materials. 
The case from Yayahuala is indicative of such a possibility. This would imply increasing power of some of the residents, who might have been competing with other residents and/or ruling elites. As I suggested above, some surplus products of lime may have been exchanged through different networks than tribute system. Such networks may have been intensified in the face of weakened tribute system.

It should be clear that there were continuous collective demands for lime plaster, and changes occurred in the realm of production and distribution/exchange. These changes would have been coterminous with changes in the values of lime plaster. The acquisition of raw materials likely became difficult relative to previous phases, and this may have resulted in the increasing relative importance of exchange values as well as values associated with production. In this way, the production and exchange of lime plaster provided a source of power to those who had an ability to organize the production and distribute the material. Therefore, the fragmented organization of production and distribution/exchange can be understood as both a cause and a consequence of competition for power among intermediate elites and/or between intermediate and ruling elites.

Manzanilla $(2006,2009)$ demonstrates that in the Early Xolalpan phase valued resources from the Gulf Coast were obtained directly by intermediate elites at the Teopancazco apartment compound, not via a central authority. It remains to be demonstrated, however, whether similar patterns can be observed in other intermediate elite compounds, but available evidence suggests that competitive acquisition of non-local resources intensified toward the end of Teotihuacan history (Murakami, 2010, n.d.).

\section{Conclusions}

While political economy has provided a framework for the study of inequality and hierarchy in early complex societies, it is clear that we need a broader framework to understand the operation of these societies, one that integrates equality and inequality in perspective. The discussion of the multidimensional nature of power relations, including the analytical separation of despotic and infrastructural power, is one such attempt. I have intended to operationalize these high-level theoretical underpinnings through (1) incorporating a materiality approach that recognizes the recursive relationship between material culture and practice, (2) placing an 
explicit focus on the constitution of demand and consumption, and (3) integrating consumption into the study of production and exchange. Specifically, I have argued that a consideration of different kinds of values (use, production, exchange, sign/symbolic, and aesthetic values) serves to better understand how demand is socially created.

A case study on lime plaster at Teotihuacan has served to illustrate the changing relationship between material culture and social relations and between production, exchange, and consumption. At the initial stage of state consolidation at Teotihuacan, lime plaster was part of material embodiment of elite power and identity, and access to this prestige item was probably regulated by elites. During the urban renewal project, lime plaster became widely accessible through the exercise of strong infrastructural power of the state. The recipe and quality of lime plaster was likely controlled by a central guild-like organization, which was probably supported by the state. Collective demand for lime plaster and some changes in the relationship between ruling elites, bureaucracy, and major social groups resulted in its wide distribution. Lime plaster became a public good and a common technological practice that embodied cooperative relations between the state and the subjects, a community of practice (Wenger, 1998), and perhaps a corporate ideology (see also Murakami, 2014, 2016). This relatively equal social relations, however, were rested on highly asymmetric power relations between Teotihuacan and lime source areas.

I emphasized that equality embodied by the use of lime plaster represents only one dimension of power relations, and it is critical to juxtapose the analysis of several different classes of artifacts to fully understand the materiality of power and identity. Along with lime plaster, construction of apartment compounds itself, their canonical orientation, and talud-tablero style temples among others may have enhanced a shared identity in the city (Murakami, 2014, 2016). I have elsewhere discussed varying patterns of production, distribution/exchange, and consumption among different classes of artifacts (Murakami, n.d.), which suggests that greenstone objects, architectural cut stone blocks, and some types of slate objects were restricted to varying degrees to intermediate and/or ruling elites throughout Teotihuacan history. Thus, both power differentials based on unequal access to resources and a shared identity grounded in equal access to resources were important mechanisms for the successful operation of the Teotihuacan polity during urban renewal. 
Toward the end of Teotihuacan history, the organization of lime plaster production and distribution became fragmented, but the continuous consumption of lime plaster was sustained by multiple groups of artisans, who might have developed their own networks or appropriated previously existing networks to obtain lime and aggregate materials. Such a fragmented organization was probably a cause and a consequence of intensified competition for power within the city, which ultimately lead to the decline of the Teotihuacan state. One of the causes of this decline may be the unresolvable and ever increasing contradiction among different dimensions of power. These changes imply that lime plaster constituted different regimes of value at different moments of Teotihuacan's history.

An object-centered approach, like the one outlined in this paper, has been employed by a number of archaeologists, particularly those who study craft production and exchange. I believe that bringing consumption to the foreground expands our understanding of the material constitution of society. It also helps to illuminate the promiscuous meaning of material objects: lime plaster constituted different regimes of value at different moments of Teotihuacan's history. In this regard, I agree with Blanton and Feinman (1984:676) that dichotomy between luxuries and bulk goods is a false one (see also Peregrine, 1992; Schneider, 1977). More importantly, there are no luxuries or commodities inherent in the nature of specific objects. Any objects are susceptible for reinterpretation, which, along with transaction forms, defines the nature of objects (Thomas, 1991). Moreover, the value of objects may change through time, as exemplified in this

study and others (e.g., Rice, 1987; Zeitlin, 1982). Such an understanding is essential for the study of human society, past and present, as social reproduction and transformation is always revolving around the material world.

\section{Acknowledgements}

I would like to thank the Consejo de Arqueología for their permission to export lime plaster samples and Alejandro Sarabia, the director of the Zona Arqueológica de Teotihuacan, for facilitating my sample collection at the site. I also thank Saburo Sugiyama, Rubén Cabrera, and Julie Gazzola for their permission to collect lime plaster samples during the Moon Pyramid Project, the Proyect La Ventilla 2004, and the Proyecto Primeras Ocupaciones en Teotihuacan at the Pre-Ciudadela respectively. Rubén Cabrera, Sergio Gómez, and Jaime Delgado shared unpublished information on La Ventilla, which greatly helped my understanding of the 
stratigraphy in this district. The study presented in this paper was financially supported by the National Science Foundation Dissertation Improvement Grant (BCS-0836716).

CL analysis was made possible through the National Science Foundation research grant (SBE0514396) to Gregory Hodgins and Arleyn Simon. Greg helped in accommodating my stay at the University of Arizona and I greatly appreciate his support. My thanks also go to Alf Lindroos for his guidance for CL analysis. A part of the results was presented in an international conference in Michoacan and comments from participants, especially Ken Hirth and Luis Barba, inspired me broadening my interpretive framework. I am grateful for edits, comments, and suggestions on an earlier draft of this paper by Shigeru Kabata, Bobbie Simova, Chris Rodning, Jason Nesbit, Willem VanEssendelft, Ryan Hechler, and two anonymous reviewers. Finally, I would like to thank Barbara Stark and George Cowgill for their kind guidance throughout the research. 


\section{References Cited}

Abrams, E.M., 1996. The evolution of plaster production and the growth of the Copan Maya state. In: Mastache, A.G., Parsons, J.R., Santley, R.S., Sera Puche, M.C. (Eds.), Arqueología Mesoamericana: Homenaje a William T. Sanders, vol. 2, Instituto Nacional de Antropología e Historia, Mexico, D.F., pp. 193-208.

Adams, R.N., 1977. Power in human societies: a synthesis. In: Fogelson, R.D., Adams, R.N. (Eds.), The Anthropology of Power. Academic Press, New York, pp. 387-410.

Algaze, G., 1993. Expansionary dynamics of some early pristine states. American Anthropologist 95, 304-333.

Appadurai, A., 1986. Introduction: commodities and the politics of value. In: Appadurai, A. (Ed.), The Social Life of Things: Commodities in Cultural Perspective. Cambridge University Press. Cambridge, pp. 3-63.

Appadurai, A., 2005. Materiality in the future of anthropology. In: van Binsbergen, W., Geschiere, P. (Eds.), Commodification: Things, Agency, and Identities (The Social Life of Things Revisited). LIT Verlag, Munster, pp. 55-62.

Bailey, D., with S. Mills (Eds.), 1998. The Archaeology of Value: Essays on Prestige and the Process of Valuation. BAR International Series 730. British Archaeological Reports, Oxford.

Baines, J., Yoffee, N., 2000. Order, legitimacy, and wealth: setting the terms. In: Richards, J., Van Buren, M. (Eds.), Order, Legitimacy, and Wealth in Ancient States. Cambridge University Press, Cambridge, pp. 13-17.

Barba, L., Blancas, J., Manzanilla, L.R., Ortiz, A., Barca, D., Crisci, G.M., Miriello, D., Pecci, A., 2009. Provenance of the limestone used in Teotihuacan (Mexico): a methodological approach. Archaeometry 51, 525-545.

Barba, L., Córdova Frunz, J.L., 1999. Estudios energéticos de la producción de cal en tiempos teotihuacanos y sus implicaciones. Latin American Antiquity 10, 168-179.

Barba Pingarrón, L.A., Córdova Frunz, J.L., 2010. Materiales y energía en la arquitectura de Teotihuacan. Instituto de Investigaciones Antropológicas, Universidad Nacional Autónoma de México, México, D.F.

Barber, S., Joyce, A., 2007. Polity produced and community consumed: negotiating political centralization through ritual in the Lower Rio Verde Valley, Oaxaca. In: Wells, E.C., DavisSalazar, K.L. (Eds.), Mesoamerican Ritual Economy: Archaeological and Ethnological Perspectives. University Press of Colorado, Boulder, pp. 221-244.

Barca, D., Miriello, D., Pecci, A., Barba, L., Ortiz, A., Manzanilla, L.R., Blancas, J., Crisci, G.M., 2013. Provenance of glass shards in archaeological lime plasters by LA-ICP-MS: 
implications for the ancient routes from the Gulf of Mexico to Teotihuacan in Central Mexico. Journal of Archaeological Science 40, 3999-4008.

Baudrillard, J., 1981[1972]. For a Critique of the Political Economy of the Sign. Telos Press, St Louis.

Baudrillard, J., 1998[1970]. The Consumer Society: Myths and Structures. Translated by Chris Turner. Sage Publication, London.

Bayly, C.A., 1986. The origins of swadeshi (home industry): cloth and Indian society, 1700-1930. In: Appadurai, A. (Ed.), The Social Life of Things: Commodities in Cultural Perspective. Cambridge University Press, Cambridge, pp. 285-321.

Bayman, J.M., 2002. Hohokam craft economies and the materialization of power. Journal of Archaeological Method and Theory 9(1): 69-95.

Berdan, F.F., 1980. Aztec merchants and markets: local-level economic activity in a nonindustrial empire. Mexicon 2, 37-41.

Blanton, R.E., 1994. Houses and Households: A Comparative Study. Plenum Press, New York.

Blanton, R.E., 1996. The Basin of Mexico market system and the growth of empire. In: Berdan, F.F., Blanton, R.E., Boone, E.H., Hodge, M.G., Smith, M.E., Umberger, E. (Eds.), Aztec Imperial Strategies. Dumbarton Oaks Research Library and Collection, Washington, D.C., pp. 47-84.

Blanton, R.E. Fargher, L.F., 2008. Collective Action in the Formation of Pre-Modern States. New York, Springer.

Blanton, R.E.,Fargher, L.F., 2011. The collective logic of pre-modern cities. World Archaeology 43(3): 505-522.

Blanton, R.E., Feinman, G.M., 1984. The Mesoamerican world systems. American Anthropologist 86, 673-682.

Blanton, R.E., Feinman, G.M., Kowalewski, S.A., Peregrine, P.N., 1996. A dual-processual theory for the evolution of Mesoamerican civilization. Current Anthropology 37, 1-14.

Blucher, D.K., 1971. Late Preclassic Cultures in the Valley of Mexico: Pre-Urban Teotihuacan. Ph.D. dissertation, Brandeis University, Waltham, MA.

Bohannan, P., 1959. The impact of money on an African subsistence economy. Journal of Economic History 19, 491-503.

Boivin, N., 2008. Material Cultures, Material Minds: The Impact of Things on Human Thought, Society, and Evolution. Cambridge University Press, Cambridge. 
Bourdieu, P., 1977. Outline of a Theory of Practice. Translated by R. Nice. Cambridge University Press, Cambridge.

Bourdieu, P., 1984. Distinction: A Social Critique of the Judgment of Taste. Transl. R. Nice. Harvard University Press, Cambridge.

Bourdieu, P., 1990. The Logic of Practice. Translated by R. Nice. Stanford University Press, Stanford.

Boynton, R.S., 1980. Chemistry and Technology of Lime and Limestone. Wiley and Sons, New York.

Braudel, F., 1981. The Structures of Everyday Life. Collins, London.

Bray, T.L. (Ed.), 2003. The Archaeology and Politics of Food and Feasting in Early States and Empires. Kluwer, New York.

Brumfiel, E.M., 1980. Specialization, market exchange, and the Aztec state: a view from Huexotla. Current Anthropology 21, 459-478.

Brumfiel, E.M., 1983. Aztec state making: ecology, structure, and origin of the state. American Anthropologist 85, 261-284.

Brumfiel, E.M., 1987a. Consumption and politics at Aztec Huexotla. American Anthropologist 89, 676-686.

Brumfiel, E.M., 1987b. Elite and utilitarian crafts in the Aztec state. In: Brumfiel, E.M., Earle, T. (Eds.), Specialization, Exchange, and Complex Societies. Cambridge University Press, Cambridge, pp. 102-118.

Brumfiel, E.M., 1991. Tribute and commerce in imperial cities: the case of Xaltocan, Mexico. In: Claessen, H.J.M., van de Velde, P. (Eds.), Early State Economics. Political and Legal Anthropology Volume 8. Transaction Publishers, New Brunswick, pp. 177-198.

Brumfiel, E.M., 1992. Breaking and entering the ecosystem—gender, class, and faction steal the show. American Anthropologist 94(3), 551-567.

Brumfiel, E.M., 2000. The politics of high culture: issues of worth and rank. In: Richards, J., Van Buren, M. (Eds.), Order, Legitimacy, and Wealth in Ancient States. Cambridge University Press, Cambridge, pp. 131-139.

Brumfiel, E.M., Fox, J.W. (Eds.), 1994. Factional Competition and Political Development in the New World. Cambridge University Press, Cambridge. 
Brumfiel, E.M., Earle, T., 1987. Specialization, exchange, and complex societies: An introduction. In: Brumfiel, E.M., Earle, T. (Eds.), Specialization, Exchange, and Complex Societies. Cambridge University Press, Cambridge, pp. 1-9.

Cabrera C., R., Gómez C., S., 2008. La Ventilla: a model for a barrio in the urban structure of Teotihuacan. In: Mastache, A.G., Cobean, R.H., García Cook, A., Hirth, K.G. (Eds.), Urbanism in Mesoamerica, Vol. 2. INAH and Pennsylvania State University, Mexico, D.F. and University Park, pp. 37-83.

Campbell, R.B. 2009. Toward a networks and boundaries approach to early complex polities: The Late Shang case. Current Anthropology 50(6), 821-848.

Carballo, D.M., 2009. Household and status in Formative Central Mexico: domestic structures, assemblages, and practices at La Laguna, Tlaxcala. Latin American Antiquity 20(3), 473-501.

Carballo, D.M., (Ed.), 2013a. Cooperation and Collective Action: Archaeological Perspectives. University Press of Colorado, Boulder.

Carballo, D.M., 2013b. The social organization of craft production and interregional exchange at Teotihuacan. In: Hirth, K.G., Pillsbury, J. (Eds.), Merchants, Markets, and Exchange in the PreColumbian World. Dumbarton Oaks Research Library and Collection, Washington, D.C., pp. $113-140$

Carballo, D.M., Carballo, J., Lesure, R.G., 2014b. Houses of style: consumption, adornment, and identity in Formative Tlaxcalan households. Ancient Mesoamerica 25, 459-476.

Carballo, D.M., Roscoe, P., Feinman, G.M., 2014a. Cooperation and collective action in the cultural evolution of complex societies. Journal of Archaeological Method and Theory 21, 98133.

Castells, M., 1978. City, Class, and Power. St. Martin’s Press, New York.

Chase-Dunn, C., Hall, T.D. (Eds.), 1997. Rise and Demise: Comparing World-Systems. Westview Press, Boulder.

Chau, L., Elliott, M. (Eds.), 2013. Distributed Objects: Meaning and Mattering after Alfred Gell. Berghahn Books, New York and Oxford.

Claessen, H.J.M., van de Velde, P. (Eds.), 1991. Early State Economics. Political and Legal Anthropology Volume 8. Transaction Publishers, New Brunswick.

Clark, J.E., Blake, M., 1994. The power of prestige: competitive generosity and the emergence of rank societies in lowland Mesoamerica. In: Brumfiel, E.M., Fox, J. (Eds.), Factional Competition and Political Development in the New World. Cambridge University Press, Cambridge, pp. 1730 . 
Clarke, J., 2012. Decorating the Neolithic: an evaluation of the use of plaster in the enhancement of daily life in the Middle Pre-Pottery Neolithic B of the southern Levant. Cambridge Archaeological Journal 22(2), 177-186.

Coote, J., Shelton, A. (Eds.), 1992. Anthropology, Art, and Aesthetics. Oxford University Press, Oxford.

Córdova F., C., 1995. Landscape Transformation in Aztec and Spanish Colonial Texcoco, Central Mexico. Ph.D. dissertation, University of Texas, Austin.

Costin, C.L., 1991. Craft specialization: issues in defining, documenting, and explaining the organization of production. Archaeological Method and Theory 3, 1-56.

Costin, C.L., 2001. Craft production systems. In: Feinman, G.M., Price, T.D. (Eds.), Archaeology at the Millenium: A Source Book. Kluwer Academic, New York, pp. 273-327.

Costin, C.L., 2004. Craft economies of ancient Andean states. In: Feinman, G.M., Nicholas, L.M. (Eds.), Archaeological Perspectives on Political Economies. The University of Utah Press, Salt Lake City, pp. 189-221.

Costin, C.L., Earle, T., 1989. Status distinction and legitimation of power as reflected in changing patterns of consumption in late Prehispanic Peru. American Antiquity 54, 691-714.

Costin, C.L., Wright, R.P. (Eds.), 1998. Craft and Social Identity. Archaeological Papers of the American Anthropological Association, 8. American Anthropological Association, Arlington, VA.

Cowgill, G.L., 2000a. “Rationality” and contexts in agency theory. In: Dobres, M.A., Robb, J. (Eds.), Agency in Archaeology. Routledge, London and New York, pp. 51-60.

Cowgill, G.L., 2000b. The Central Mexican Highlands from the rise of Teotihuacan to the decline of Tula. In: Adams, R.E.W., MacLeod, M.J. (Eds.), The Cambridge History of the Native Peoples of the Americas. Volume II: Mesoamerica, Part 1. Cambridge University Press, Cambridge, pp. 250-317.

Cowgill, G.L., 2007. The urban organization of Teotihuacan, Mexico. In: Stone, E.C. (Ed.), Settlement and Society: Essays Dedicated to Robert McCormick Adams. Cotsen Institute of Archaeology, University of California and the Oriental Institute of the University of Chicago, Los Angeles and Chicago, pp. 261-295.

Cowgill, G.L., 2015. Ancient Teotihuacan: Early Urbanism in Central Mexico. Cambridge University Press, Cambridge.

Croissier, M.M., 2007. The Zapotec Presence at Teotihuacan, Mexico: Political Ethnicity and Domestic Identity. Ph.D. Dissertation, Department of Anthropology, University of Illinois at Urbana-Champaign. 
D’Altoroy, T.N., Earle, T.K., 1985. Staple finance, wealth finance, and storage in the Inca political economy. Current Anthropology 26, 187-206.

Davis-Salazar, K.L., 2007. Ritual consumption and the origins of social inequality in Early Formative Copán, Honduras. In: Wells, E.C., Davis-Salazar, K.L. (Eds.), Mesoamerican Ritual Economy: Archaeological and Ethnological Perspectives. University Press of Colorado, Boulder, pp. 197-220.

DeMarrais, E., Castillo, L.J., Earle, T., 1996. Ideology, materialization, and power strategies. Current Anthropology 37(1), 15-31.

DeMarrais, E., Gosden, C., Renfrew, C. (Eds.), 2004. Rethinking Materiality: The Engagement of Mind with the Material World. McDonald Institute for Archaeological Research, University of Cambridge, Cambridge.

Díaz Oyarzábal, C.L., 1980. Chingú: Un sitio Clásico del área de Tula, Hgo. Colección Científica, núm. 90. Instituto Nacional de Antropología e Historia, México, D.F.

Dietler, M., 2005. The archaeology of colonization and the colonization of archaeology: theoretical challenges from an ancient Mediterranean colonial encounter. In: Stein, G.J. (Ed.), The Archaeology of Colonial Encounters: Comparative Perspectives. School of American Research Press, Santa Fe, pp. 33-68.

Dietler, M., Hayden, B. (Eds.), 2001. Feasts: Archaeological and Ethnographic Perspectives on Food, Politics, and Power. Smithsonian Institution Press, Washington, D.C.

Dilley, R., 2005. The Visibility and invisibility of production: in different social contexts among Senegalese craftsman. In: van Binsbergen, W., Geschiere, P. (Eds.), Commodification: Things, Agency, and Identities (The Social Life of Things Revisited). LIT Verlag, Munster, pp. 227-241.

Dobres, M-A., Hoffman, C.R. (Eds.), 1999. The Social Dynamics of Technology: Practice, Politics, and World Views. Smithsonian Institution Press, Washington, D.C.

Douglas, M., 1967. Primitive rationing. In: Firth, R. (Ed.), Themes in Economic Anthropology. Tavistock, London, pp. 119-147.

Douglas, M., Isherwood, B., 1979. The World of Goods. Allen Lake, London.

Drazin, A., Küchler, S., 2015. The Social Life of Materials: Studies in Material and Society. Bloomsbury Academic, London.

Earle, T.K., 1997. How Chiefs Come to Power: The Political Economy of Prehistory. Stanford University Press, Stanford. 
Earle, T.K., 2002. Bronze Age Economics: The Beginnings of Political Economies. Westview Press, Boulder.

Ehrenreich, R.M., Crumley, C.L., Levy, J.E. (Eds.), 1995. Heterarchy and the Analysis of Complex Societies. Archaeological Papers 6. American Anthropological Association, Washington, D.C.

Eisenstadt, S.N., 1963. The Political Systems of Empires. The Free Press of Glencoe, London.

Emberling, G., 1999. The value of tradition: The development of social identities in early Mesopotamian states. In: Robb, J.E. (Ed.), Material Symbols: Culture and Economy in Prehistory. Occasional Paper No. 26, Center for Archaeological Investigations. Southern Illinois University, Carbondale, pp. 277-301.

Epstein, S.A., 1991. Wage Labor and Guilds in Medieval Europe. University of North Carolina Press, Chapel Hill.

Fargher, L.F., Blanton, R.E., Heredia Espinoza, V.Y., 2010. Egalitarian ideology and political power in prehispanic central Mexico: the case of Tlaxcallan. Latin American Antiquity 21, 227251.

Fargher, L.F., Heredia Espinoza, V.Y., Blanton, R.E., 2011. Alternative pathways to power in late Postclassic Highland Mesoamerica. Journal of Anthropological Archaeology 30, 306-326.

Feinman, G.M., Upham, S., Lightfoot, K.G., 1981. The production step measure: an ordinal index of labor input in ceramic manufacture. American Antiquity 46, 871-885.

Feinman, G.M., Nicholas, L.M. (Eds.), 2004. Archaeological Perspectives on Political Economies. The University of Utah Press, Salt Lake City, pp. 129-144.

Feinman, G.M., Nicholas, L.M., Haines, H.R., 2006. Socioeconomic inequality and the consumption of chipped stone at El Palmillo, Oaxaca, Mexico. Latin American Antiquity 17, $151-175$.

Ferguson, Y., Mansbach, R., 1996. Polities: Authority, Identities, and Change. University of South Carolina Press, Columbia.

Flad, R., 2012. Bronze, jade, gold, and ivory: valuable objects in ancient Sichuan. In: Papadopoulos, J.K., Urton, G. (Eds.), The Construction of Value in the Ancient World. Cotsen Institute of Archaeology Press, University of California, Los Angeles, pp. 306-335.

Freidel, D.A., Reese-Taylor, K., Mora-Marín, D., 2002. The origins of Maya civilization: the old shell game, commodity, treasure, and kingship. In: Masson, M.A., Freidel, D.A. (Eds.), Ancient Maya Political Economies. Altamira Press, Walnut Creek, pp. 41-86.

Friedman, J., (Ed.), 1994. Consumption and Identity. Harwood Academic, Amsterdam. 
García Cook, A., 1981. The historical importance of Tlaxcala. In: Bricker, V., Sabloff, J. A. (Eds.), Supplement to the Handbook of Middle American Indians, vol.1: Archaeology. University of Texas Press, Austin, pp. 244-276.

Garraty, C.P., Stark, B.L. (Eds.), 2010. Archaeological Approaches to Market Exchange in Ancient Societies. University Press of Colorado, Boulder.

Gazzola, J., 2009. Características arquitectónicas de algunas construcciones de fases tempranas en Teotihuacán. Arqueología 42, 216-233.

Gell, A., 1986. Newcomers to the world of goods: Consumption among the Muria Gonds. In: Appadurai, A. (Ed.), The Social Life of Things: Commodities in Cultural Perspective. Cambridge University Press, Cambridge, pp. 110-138.

Gell, A., 1992. The technology of enchantment and the enchantment of technology. In: Coote, J., Shelton, A. (Eds.), Anthropology, Art, and Aesthetics. Oxford University Press, Oxford, pp. 4063.

Gell, A., 1998. Art and Agency: An Anthropological Theory. Clarendon Press, Oxford.

Giddens, A., 1979. Central Problems in Social Theory. University of California Press, Berkeley.

Giddens, A., 1984. The Constitution of Society: Outline of the Theory of Structuration. University of California Press, Berkeley and Los Angeles.

Godelier, M., 1999[1996]. The Enigma of the Gift. Scott, N., trans. University of Chicago Press, Chicago.

Gómez Chávez, S., 2000. La Ventilla: un barrio de la antigua ciudad de Teotihuacán. Tesis for licenciatura. Escuela Nacional de Antropología e Historia, México, D.F.

González Licón, E., 2009. Ritual and social stratification at Monte Albán, Oaxaca: strategies from a household perspective. In: Manzanilla, L.R., Chapdelaine, C. (Eds.), Domestic Life in Prehispanic Capitals: A Study of Specialization, Hierarchy, and Ethnicity. Museum of Anthropology, University of Michigan, Ann Arbor, pp. 7-20.

Goodwin, C., 1994. Professional vision. American Anthropologist 96(3), 606-633.

Gosden, C., 2013. Technologies of routine and enchantment. In: Chau, L., Elliott, M. (Eds.), Distributed Objects: Meaning and Mattering after Alfred Gell. Berghahn Books, New York and Oxford, pp. 39-57.

Gosselain, O., 2000. Materializing identities: an African perspective. Journal of Archaeological Method and Theory 7, 187-217. 
Gow, P., 1999. Piro designs: painting as meaningful action in an Amazonian lived world. Journal of the Royal Anthropological Institute (n.s.) 5, 229-246.

Graeber, D., 2001. Toward an Anthropological Theory of Value: The False Coin of Our Own Dreams. Palgrave, New York.

Graeber, D., 2011. Consumption. Current Anthropology 52(4), 489-511.

Graham, E., 2002. Perspectives on economy and theory. In: Masson, M.A., Freidel, D.A. (Eds.), Ancient Maya Political Economies. Altamira Press, Walnut Creek, pp. 398-418.

Gregory, C.A., 1982. Gifts and Commodities. Academic Press, New York.

Haller, M.J., Feinman, G.M., Nicholas, L.M. (2006). Socioeconomic inequality and differential access to faunal resources at El Palmillo, Oaxaca, Mexico. Ancient Mesoamerica 17, 39-55.

Hale, J., Heinemeier, J., Lancaster, L., Lindroos, A., Ringbom, A., 2003. Dating ancient mortar. American Scientist 91(2), 130-138.

Halperin, C.T., Foias, A.E., 2010. Pottery politics: Late Classic Maya palace production at Motul de San José, Petén, Guatemala. Journal of Anthropological Archaeology 29, 392-411.

Hansen, E., 2000. Ancient Maya Burnt-Lime Technology: Cultural Implications of Technological Styles. Ph.D. dissertation, University of California, Berkeley.

Harrison, R., 2007. Materiality, “ambiguity” and the unfamiliar in the archaeology of intersocietal confrontations: a case study from Northwest Australia. In: Cornell, P., Fahlander, F. (Eds.), Encounters, Materialities, Confrontations: Archaeologies of Social Space and Interaction. Cambridge Scholars, Newcastle, pp. 42-57.

Haug, W.F., 1986. Critique of Commodity Aesthetics. Polity Press, Cambridge.

Hayden, B., 1998. Practical and prestige technologies: the evolution of material systems. Journal of Archaeological Method and Theory 5, 1-55.

Heinemeier, J., Jungner, H., Lindroos, A., Ringbom, Á., von Konow, T., Rud, N., 1997. AMS 14C dating of lime mortar. Nuclear Instruments and Methods in Physics Research B 123, 487495.

Helms, M.W., 1988. Ulysses' Sail: An Ethnographic Odyssey of Power, Knowledge, and Geographical Distance, Princeton University Press, Princeton.

Helms, M.W., 1993. Craft and the Kingly Ideal: Art, Trade, and Power. University of Texas Press, Austin. 
Hendon, J.A., 2000. Having and holding: storage, memory, knowledge, and social relations. American Anthropologist 102, 42-53.

Hendon, J.A., 2005. Memory, materiality, and practice: house societies in southeastern Mesoamerica. In: Beck, R. (Ed.), The Durable House: House Society Models in Archaeology. Center for Archaeological Investigations, Carbondale, pp. 292-316.

Hirth, K.G., 1993. Identifying rank and socioeconomic status in domestic contexts: an example from central Mexico. In: Santley, R.S., Hirth, K.G. (Eds.), Prehispanic Domestic Units in Western Mesoamerica: Studies of the Household, Compound, and Residence. CRC Press, Boca Raton, FL, pp. 121-146.

Hirth, K.G., 1996. Political economy and archaeology: perspectives on exchange and production. Journal of Archaeological Research 4(3), 203-239.

Hirth, K.G., 1998. The distributional approach: a new way to identify marketplace exchange in the archaeological record. Current Anthropology 39, 451-476.

Hirth, K.G., 2009. Household, workshop, guild, and barrio: The organization of obsidian craft production in a prehispanic urban center. In: Manzanilla, L., Chapdelaine, C. (Eds.), Domestic Life in Prehispanic Capitals: A Study of Specialization, Hierarchy, and Ethnicity. Memoirs of the Museum of Anthropology, University of Michigan, No. 46, Vol. VII, Ann Arbor, pp. 43-65.

Hirth, K.G., Bonder, G., Glascock, M., Vonarx, A.J., Daubenspeck, T., 2006. Supply side economics: An analysis of obsidian procurement and the organization of workshop provisioning. In: Hirth, K.G. (Ed.), Obsidian Craft Production in Ancient Central Mexico. University of Utah Press, Salt Lake City, pp. 115-136.

Hirth, K.G., Pillsbury, J. (Eds.), 2013. Merchants, Markets, and Exchange in the Pre-Columbian World. Dumbarton Oaks Research Library and Collection, Washington, D.C.

Hutson, S., 2010. Dwelling, Identity, and the Maya: Relational Archaeology at Chunchucmil. AltaMira, Lanham.

Ingold, T. (Ed.), 1996. 1993 debate: aesthetics is a cross cultural category. In: Key Debates in Anthropology. Routledge, London, pp. 249-293.

Inomata, T., 2001. The power and ideology of artistic creation: elite craft specialists in Classic Maya society. Current Anthropology 42(3), 321-349.

Inomata, T., 2006. Plazas, performers, and spectators: political theaters of Classic Maya. Current Anthropology 47(5), 805-842.

Janusek, J., 2004. Identity and Power in the Ancient Andes: Tiwanaku Cities through Time. Routledge, New York. 
Johnson, A., Earle, T.K, 2000. The Evolution of Human Societies: From Foraging Group to Agrarian State. Second Edition. Stanford University Press, Stanford.

Joyce, A., Weller, E., 2007. Commoner rituals, resistance, and the Classic to Postclassic transition in ancient Mesoamerica. In: Gonlin, N., Lohse, J. (Eds.), Commoner Ritual and Ideology in Ancient Mesoamerica. University Press of Colorado, Boulder, pp. 143-184.

Kabata, S., Murakami, T., 2013. Informe técnico de la primera temporada del Proyecto Arqueológico Tlalancaleca, Puebla. A report submitted to the Consejo de Arqueología, el Instituto Nacional de Antropología e Historia, México, D.F.

Kabata, S., Murakami, T., 2014. Informe técnico de la segunda temporada del Proyecto Arqueológico Tlalancaleca, Puebla. A report submitted to the Consejo de Arqueología, el Instituto Nacional de Antropología e Historia, México, D.F.

Kalavrezou, I., 2012. Light and the precious object, or value in the eyes of the Byzantines. In: Papadopoulos, J.K., Urton, G. (Eds.), The Construction of Value in the Ancient World. Cotsen Institute of Archaeology Press, University of California, Los Angeles, pp. 354-369.

Kamp, K.E., 1993. Towards an archaeology of architecture: clues from a modern Syrian village. Journal of Anthropological Research 49, 293-317.

Kopytoff, I., 1986. The cultural biography of things: commoditization as process. In: Appadurai, A. (Ed.), The Social Life of Things: Commodities in Cultural Perspective. Cambridge University Press, Cambridge, pp. 64-91.

Kovacevich, B., Callaghan, M.G. (Eds.), 2013. Archaeological Papers of the American Anthropological Association 23(1). American Anthropological Association, Arlington, VA.

Kurnick, S., Baron, J. (Eds.), 2016. Political Strategies in Pre-Columbian Mesoamerica. University of Colorado Press, Boulder.

Latour, B., 1993. We Have Never Been Modern. Translated by C. Porter. Harvard University Press, Cambridge.

Latour, B., 2005. Reassembling the Social: An Introduction to Actor-Network-Theory. Oxford University Press, Oxford.

Lenski, G.E., 1966. Power and Privilege: A Theory of Social Stratification. McGraw-Hill, New York.

Lesure, R.G., 1999. On the genesis of value in early hierarchical societies. In: Robb, J.E. (Ed.), Material Symbols: Culture and Economy in Prehistory. Occasional Paper No. 26, Center for Archaeological Investigations. Southern Illinois University, Carbondale, pp. 23-55. 
Lesure, R.G., 2004. Shared art styles and long-distance contact in early Mesoamerica. In: Hendon, J.A., Joyce, R.A. (Eds.), Mesoamerican Archaeology: Theory and Practice. Blackwell Publishing, Malden, MA, pp. 73-96.

Lesure, R.G., Blake, M., 2002. Interpretive challenges in the study of early complexity: economy, ritual, and architecture at Paso de la Amada, Mexico. Journal of Anthropological Archaeology 21, $1-24$.

Levi, M., 1988. Of Rule and Revenue. University of California Press, Berkeley.

Levine, M., 2011. Negotiating political economy at Late Postclassic Tututepec (Yucu Dzaa), Oaxaca, Mexico. American Anthropologist 11, 22-39.

Lindroos, A., 2005. Carbonate Phases in Historical Lime Mortars and Pozzolana Concrete: Implications for 14C Dating. Dissertation, Department of Geology and Mineralogy, Åbo Akademi University, Åbo, Finland.

Lillios, K.T., 1999. Objects of memory: the ethnography and archaeology of heirlooms. Journal of Archaeological Method and Theory 6(3), 235-262.

Lindroos, A., Heinemeier, J., Ringbom, Å., Braskén, M., Sveinbjörnsdóttir, A., 2007. Mortar dating using AMS 14C and sequential dissolution: examples from Medieval, non-hydraulic lime mortars from the Åland Islands, SW Finland. Radiocarbon 49(1), 47-67.

Linné, S., 1934. Archaeological Researches at Teotihuacan, Mexico. The Ethnographical Museum of Sweden, n.s., 1., Stockholm.

Linné, S., 1942. Mexican Highland Cultures, Archaeological Researches at Teotihuacan, Calpulalpan and Chalchicomula in 1934/35. The Ethnographic Museum of Sweden, Stockholm.

Lizárraga, Y., Ortiz Butrón, A., 1993. Hacia una reinterpretación de los “pulidores de estuco.” In: Manzanilla, L. (Coord.), Anatomía de un conjunto residencial teotihuacano en Oztoyahualco I: Las excavaciones. Instituto de Investigaciones Antropológicas, Universidad Nacional Autónoma de México, Mexico, D.F., pp. 468-493.

Lohse, J.C., Valdez, F. (Eds.), 2004. Ancient Maya Commoners. University of Texas Press, Austin.

López Luján, L., Torres, J., Montúfar, A., 2003. Los materiales constructivos del Templo Mayor de Tenochtitlan. Estudios de Cultura Náhuatl 34, 137-166.

López Luján, L., Filloy Nadal, L., Fash, B. W., Fash, W. L., Hernández, P., 2006. The destruction of images in Teotihuacan: Anthropomorphic sculpture, elite cults, and the end of a civilization. RES: Journal of Anthropology and Aesthetics 49/50, 13-39. 
Magaloni, D., 1996. El espacio pictórico teotihuacano. Tradición y técnica. In: de la Fuente, B. (Ed.), La pintura mural prehispánica en México I: Teotihuacán. Tomo II: Estudios. Universidad Nacional Autónoma de México and Instituto de Investigaciones Estéticas, Mexico, D.F., pp. 187225.

Magaloni, D., Falcon, T., Cama, J., Siegel, R.W., Lee, R., Pancella, R., Baños, L., Castaño, V., 1992. Electron microscopy studies of the chronological sequences of Teotihuacan plaster technique. Material Issues in Art and Archaeology 3 (267), 997-1005.

Malinowski, B., 1922. Argonauts of Western Pacific: An Account of Native Enterprise and Adventure in the Archipelagoes of Melanesian New Guinea. Studies in Economics and Political Science, no. 65. Routledge, London.

Mann, M., 1984. The autonomous power of the state: its origins, mechanisms and results. European Journal of Sociology 25, 185-213.

Mann, M., 1986. The Sources of Social Power, Volume 1: A History of Power from the Beginning to A.D. 1760. Cambridge University Press, Cambridge.

Manzanilla, L., 1993a. Ensayo de interpretación. In: Manzanilla, L. (Coord.), Anatomía de un conjunto residencial teotihuacano en Oztoyahualco I: las excavaciones. Instituto de Investigaciones Antropológicas, Universidad Nacional Autónoma de México, Mexico, D.F., pp. 548-566.

Manzanilla, L., 1993b. Arquitectura y áreas de actividad: banco de datos. In: Manzanilla, L. (Coord.), Anatomía de un conjunto residencial teotihuacano en Oztoyahualco I: las excavaciones. Instituto de Investigaciones Antropológicas, Universidad Nacional Autónoma de México, Mexico, D.F., pp. 98-189.

Manzanilla, L., 2004. Social identity and daily life at Classic Teotihuacan. In: Hendon, J.A., Joyce, R.A. (Eds.), Mesoamerican Archaeology: Theory and Practice. Blackwell Publishing, Oxford, pp. 124-147.

Manzanilla, L., 2006. Estados corporativos arcaicos. organizaciones de excepción en escenarios excluyentes. Cuicuilco 13(36), 13-45.

Manzanilla, L., 2009. Corporate life in apartment and barrio compounds at Teotihuacan, Central Mexico: craft specialization, hierarchy, and ethnicity. In: Manzanilla, L., Chapdelaine, C. (Eds.), Domestic Life in Prehispanic Capitals: A Study of Specialization, Hierarchy, and Ethnicity. Memoirs of the Museum of Anthropology, University of Michigan, No. 46, Vol. VII, Ann Arbor, pp. 21-42.

Marshall, D. J., 1988. Cathodoluminescence of Geological Materials. Unwin Hyman, Boston, MA. 
Masson, M.A., 2002. Inroduction. In: Masson, M.A., Freidel, D.A. (Eds.), Ancient Maya Political Economies. Altamira Press, Walnut Creek, pp. 1-30.

Mastache, A.G., Cobean, R.H., Healan, D.M., 2002. Ancient Tollan: Tula and the Toltec Heartland. University Press of Colorado, Boulder.

Mauss, M., 2000[1929]. The Gift: The Form and Reason for Exchange in Archaic Societies. Translated by W. D. Halls. W. W. Norton, New York and London.

McAnany, P.A., 1991. Structure and dynamics of intercommunity exchange. In: Hester, T.R., Shafer, H.J. (Eds.), Maya Stone Tools: Selected Papers from the Second Maya Lithic Conference. Prehistory Press, Madison, pp. 271-293.

McGuire, R.H., 1983. Breaking down cultural complexity: inequality and heterogeneity. Advances in Archaeological Method and Theory 6, 91-142.

Miller, D., 1987. Material Culture and Mass Consumption. Basil Blackwell, Oxford.

Miller, D. (Ed.), 1995. Acknowledging Consumption: A Review of New Studies. Routledge, London.

Miller, D. (Ed.), 2001. Consumption: Critical Concepts in the Social Sciences. Taylor \& Francis, London.

Millon, R., 1981. Teotihuacan: city, state, and civilization. In: Bricker, V., Sabloff, J.A. (Eds.), Supplement to the Handbook of Middle American Indians, vol.1: Archaeology. University of Texas Press, Austin, pp. 198-243.

Millon, R., 1988. The last years of Teotihuacan dominance. In: Yoffee, N., Cowgill, G.L. (Eds.), The Collapse of Ancient States and Civilizations. University of Arizona Press, Tucson, pp. 102164.

Millon, R., 1993. The place where time began: an archaeologist's interpretation of what happened in Teotihuacan history. In: Berrin, K., Pasztory, E. (Eds.), Teotihuacan: Art from the City of the Gods. Thames and Hudson and the Fine Arts Museums of San Francisco, pp. 17-43.

Millon, R., Bennyhoff, J.A., 1961. A long architectural sequence at Teotihuacan. American Antiquity 26(4), 516-523.

Mills, B. J., 2004. The establishment and defeat of hierarchy: Inalienable possessions and the history of collective prestige structures in the Pueblo southwest. American Anthropologist 106(2), 238-251.

Morphy, H., 1991. Ancestral Connections: Art and an Aboriginal System of Knowledge. University of Chicago Press, Chicago. 
Morris, E.H., Charlot, J., Morris, A.A., 1931. The Temple of the Warriors at Chichen Itza, Yucatan. Publication No. 406. Carnegie Institution of Washington, Washington D.C.

Mukerji, C., 1983. From Graven Images. Columbia University Press.

Mullins, P.R., 2011. The archaeology of consumption. Annual Review of Anthropology 40, 133-144.

Munn, N., 1986. The Fame of Gawa: A Symbolic Study of Value Transformation in a Massim (Papua New Guinea) Society. Cambridge University Press, Cambridge.

Murakami, T., 2010. Power Relations and Urban Landscape Formation: A Study of Construction Labor and Resources at Teotihuacan, Mexico. Ph.D. dissertation, Arizona State University, Tempe.

Murakami, T., 2013. Persistent technology, changing social relations: Urban architecture at Teotihuacan. Paper presented at the XXXV Coloquio de Antropología e Historia Regionales "El Pasado tecnológico: Cambio y persistencia.” El Colegio de Michoacán, Zamora, Mexico.

Murakami, T., 2014. Social identities, power relations, and urban transformations: politics of plaza construction at Teotihuacan. In: Tsukamoto, K., Inomata, T. (Eds.), Mesoamerican Plazas: Arenas of Community and Power. University of Arizona Press, Tucson, pp. 34-49.

Murakami, T., 2015. Replicative construction experiments at Teotihuacan: Assessing the duration and timing of monumental construction. Journal of Field Archaeology 40(3), 263-282.

Murakami, T., 2016. Entangled political strategies: Rulership, bureaucracy, and intermediate elites at Teotihuacan. In: Kurnick, S., Baron, J. (Eds.), Political Strategies in Pre-Columbian Mesoamerica. University Press of Colorado, Boulder, pp. 153-180.

Murakami, T., n.d. Political dynamics and non-local resources at Teotihuacan: Interregional interaction viewed from the metropolis. In: Garcia-Des Laurier, C., Murakami, T., (Eds.), Teotihuacan and Early Classic Mesoamerica: Multi-Scalar Perspective on Power, Identity, and Interregional Interaction. University Press of Colorado, Boulder. Manuscript in preparation.

Murakami, T., Hodgins, G., Simon, A.W., 2013. Characterization of lime carbonates in plasters from Teotihuacan, Mexico: Preliminary results of cathodoluminescence and carbon isotope analyses. Journal of Archaeological Science 40, 960-970.

Myers, F.R. (Ed.), 2001. The Empire of Things: Regimes of Value and Material Culture. SAR Press, Santa Fe, NM.

Nazaroff, A.J., Tsoraki, C., Vasic, M., 2016. Aesthetic, social, and material networks: a perspective from the Flint Daggers at Çatalhöyük, Turkey. Cambridge Archaeological Journal 26, 65-92. 
O’Brien, P.J., 1991. Early state economics: Cahokia, capital of the Ramey state. In: Claessen, H.J.M., van de Velde, P. (Eds.), Early State Economics. Political and Legal Anthropology Volume 8. Transaction Publishers: New Brunswick, pp. 143-176.

Ortner, S.B., 1984. Theory in anthropology since the sixties. Comparative Studies in Society and History 26, 126-166.

Ossa, A. 2013. Using network expectations to identify multiple exchange systems: a case study from Postclassic Sauce and its hinterland in Veracruz, Mexico. Journal of Anthropological Archaeology 32, 415-432.

Papadopoulos, J.K., Urton, G., 2012a. Introduction. In: Papadopoulos, J.K., Urton, G. (Eds.), The Construction of Value in the Ancient World. Cotsen Institute of Archaeology Press, University of California, Los Angeles, pp. 1-47.

Papadopoulos, J.K., Urton, G. (Eds.), 2012b. The Construction of Value in the Ancient World. Cotsen Institute of Archaeology Press, University of California, Los Angeles.

Parsons, J.R., Gorenflo, L.J., 2008. The Patterning of settlement. In: Parsons, J.R. (Ed.), Prehispanic Settlement Patterns in the Northwestern Valley of Mexico: The Zumpango Region. Museum of Anthropology Memoirs, No. 45. University of Michigan, Ann Arbor, pp. 61-99.

Paynter, R., McGuire, R.H., 1991. The archaeology of inequality: material culture, domination and resistance. In: McGuire, R.H., Paynter, R. (Eds.), The Archaeology of Inequality. Basil Blackwell, Oxford, pp. 1-27.

Peregrine, P.N., 1992. Mississippian Evolution: A World-System Perspective. Prehistory Press, Madison.

Pinney, C., Thomas, N. (Eds.), 2001. Beyond Aesthetics: Art and the Technologies of Enchantment. Berg, Oxford.

Piña Chan, R., 1963. Excavaciones en el rancho La Ventilla. In: Bernal, I. (comp.), Teotihuacan. Instituto Nacional de Antropología e Historia, Mexico, D.F., pp. 50-52.

Plourde, A.M., 2008. The origins of prestige goods as honest signals of skill and knowledge. Human Nature 19(4), 374-388.

Plunket, P., Uruñuela, G., 1998. Preclassic household patterns preserved under volcanic ash at Tetimpa, Puebla, Mexico. Latin American Antiquity 9(4), 287-309.

Polanyi, K. 1944. The Great Transformation. Farrar \& Rinehart, Inc., New York.

Porter, J.I., 2012. The value of aesthetic value. In: Papadopoulos, J.K., Urton, G. (Eds.), The Construction of Value in the Ancient World. Cotsen Institute of Archaeology Press, University of California, Los Angeles, pp. 336-353. 
Pool, C.A., Bey, G.J., III (Eds.), 2007. Pottery Economics in Mesoamerica. The University of Arizona Press, Tucson.

Preteceille, E.,Terrail, J-P., 1985. Capitalism, Consumption and Needs. Basil Blackwell, Oxford.

Raab, L.M., Goodyear, A.C., 1984. Middle range theory in archaeology: a critical review of origins and applications. American Antiquity 49(2), 255-268.

Ramachandran, V.S., 2011. The Tell-Tale Brain: A Neuroscientist’s Quest for What Makes Us Human. W.W. Norton, New York.

Rathje, W.L., 1972. Praise the gods and pass the metates: a hypothesis of the development of lowland rainforest civilizations in Mesoamerica. In: Leone, M.P. (Ed.), Contemporary Archaeology: A Guide to Theory and Contributions. Southern Illinois University Press, Carbondale, pp. 365-392.

Rattray, E.C., 1997. Entierros y Ofrendas en Teotihuacan: Excavaciones, inventario, patrones mortuarios. Instituto de Investigaciones Antropológicas, Universidad Autónoma de México, México, D.F.

Renfrew, C., 1986. Varna and the emergence of wealth in prehistoric Europe. In: Appadurai, A. (Ed.), The Social Life of Things: Commodities in Cultural Perspective. Cambridge University Press, Cambridge, pp. 141-169.

Rice, P.M., 1987. Economic change in the lowland Maya Late Classic period. In: Brumfiel, E.M., Earle, T. (Eds.), Specialization, Exchange, and Complex Societies. Cambridge University Press, Cambridge, pp. 76-85.

Robb, J.E. (Ed.), 1999. Material Symbols: Culture and Economy in Prehistory. Occasional Paper No. 26, Center for Archaeological Investigations. Southern Illinois University, Carbondale.

Roscoe, P., 1995. Of power and menace: Sepik art as an affecting presence. Journal of the Royal Anthropological Institute 1(1), 1-22.

Roseberry, W., 1988. Political economy. Annual Review of Anthropology 17, 161-185.

Rutz, H.J., Orlove, B.S. (Eds.), 1989a. The Social Economy of Consumption. Monographs in Economic Anthropology, No. 6. University Press of America, Lanham.

Rutz, H.J., Orlove, B.S., 1989b. Thinking about consumption: A social economy approach. In: Rutz, H.J., Orlove, B.S. (Eds.), The Social Economy of Consumption. Monographs in Economic Anthropology, No. 6. University Press of America, Lanham, pp. 1-57.

Sahlins, M., 1976. Culture and Practical Reason. University of Chicago Press, Chicago. 
Sahlins, M., 1981. Historical Metaphors and Mythical Realities: Structure in the Early History of the Sandwich Islands Kingdom. University of Michigan Press, Ann Arbor.

Salisbury, R., 1962. From Stone to Steel. Cambridge University Press, Cambridge.

Scarborough, V.L., Clark, J.E. (Eds.), 2007. The Political Economy of Ancient Mesoamerica: Transformations during the Formative and Classic Periods. University of New Mexico Press, Albuquerque.

Scaramelli, F., de Scaramelli, K.T., 2005. The roles of material culture in the colonization of the Orinoco, Venezuela. Journal of Social Archaeology 5(1), 135-168.

Schneider, J., 1977. Was there a pre-capitalist world system? Peasant Studies 6, 20-29.

Schneider, J., 1978. Peacocks and penguins: the political economy of European cloth and colors. American Ethnologist 5(3), 413-447.

Schortman, E., Urban, P., 2004. Modeling the roles of craft production in ancient political economies. Journal of Archaeological Research 12(2), 185-226.

Schortman, E., Urban, P., 2012. Enacting power through networks. Journal of Anthropological Archaeology 31, 500-514.

Schortman, E., Urban, P., Ausec, M., 2001. Politics with style: identity formation in Prehispanic southeastern Mesoamerica. American Anthropologist 103, 312-330.

Schreiner, T.P., 2002. Traditional Maya Lime Production: Environmental and Cultural Implications of a Native American Technology. Ph.D. dissertation, University of California, Berkeley.

Schucany, C., 2005. Cooking like a native, dining like a Roman: food preparation and consumption in Roman Switzerland. In: Carroll, M., Hadley, D.M., Wilmott, H. (Eds.), Consuming Passions: Dining from Antiquity to the Eighteenth Century. Tempus, Stroud, pp. 3948.

Scott, J.C., 1990. Domination and the Arts of Resistance: Hidden Transcripts. Yale University Press, New Haven.

Sejourné, L., 1966. Arquitectura y Pintura en Teotihuacán. Siglo XXI, México, D.F.

Sewell, W.H., Jr., 1992. A theory of structure: duality, agency, and transformation. The American Journal of Sociology 98(1), 1-29.

Shelton, A., 1992. Predicates of aesthetic judgment: ontology and value in Huichol material representations. In: Coote, J., Shelton, A. (Eds.), Anthropology, Art, and Aesthetics. University of Oxford Press, Oxford, pp. 209-244. 
Shenwan Al-Bashaireh, K. 2008. Chronology and Technological Production Styles of Nabatean and Roman Plasters and Mortars at Petra (Jordan). Ph.D. Dissertation, University of Arizona, Tucson.

Shimada, I. (Ed.), 2008. Craft Production in Complex Societies: Multicraft and Producer Perspectives. The University of Utah Press, Salt Lake City.

Simmel, G., 1978[1907]. The Philosophy of Money. Routledge and Kegan Paul, London.

Sinopoli, C., 1988. The organization of craft production at Vijayanagara, South India. American Anthropologist 90, 580-597.

Skeates, R., 2010. An Archaeology of the Senses: Prehistoric Malta. Oxford University Press, Oxford.

Small, D.B., 2009. The dual-processual model in ancient Greece: applying a postneoevolutionary model to a data-rich environment. Journal of Anthropological Archaeology 28, 205-221.

Smith, A.T., 2011. Archaeology of sovereignty. Annual Review of Anthropology 40, 415-432.

Smith, M. E., 1987. Household possessions and wealth in agrarian states: implications for archaeology. Journal of Anthropological Archaeology 6, 297-335.

Spence, M.W., 1992. Tlailotlacan, a Zapotec enclave in Teotihuacan. In: Berlo, J.C. (Ed.), Art, Ideology, and the City of Teotihuacan. Dumbarton Oaks, Washington, D.C., pp. 59-88.

Spence, M.W., 1996. Commodity or gift: Teotihuacan obsidian in the Maya region. Latin American Antiquity 7(1), 21-39.

Spensley, E., 2004. Micromorphology of Construction and Culture at Trinidad de Nosotros, Peten, Guatemala. M.A. thesis, Boston University, Boston.

Stark, M.T., 1999. Social dimensions of technical choice in Kalinga ceramic traditions. In: Chilton, E.S. (Ed.), Material Meanings: Critical Approaches to the Interpretation of Material Culture. The University of Utah Press, Salt Lake City, pp. 24-43.

Steel, L., 2002. Consuming passions: a contextual study of the consumption of Mycenaean pottery at Tell el-'Ajjul. Journal of Mediterranean Archaeology 15(1), 25-54.

Steel, L., 2013. Materiality and Consumption in the Bronze Age Mediterranean. Routledge, New York and London. 
Stein, G., 1998. Heterogeneity, power and political economy: some current research issues in the archaeology of Old World complex societies. Journal of Archaeological Research 6, 144.

Strathern, M., 1992. Qualified value: the perspective of gift exchange. In: Humphrey, C., HughJones, S. (Eds.), Barter, Exchange and Value: An Anthropological Approach. Cambridge University Press, Cambridge, pp. 169-191.

Sugiyama, S., 1998. Termination programs and prehispanic looting at the Feathered Serpent Pyramid in Teotihuacan, Mexico. In: Mock, S.B. (Ed.), The Sowing and the Dawning. University of New Mexico Press, Albuquerque, pp. 146-164.

Sugiyama, S., 2004. Governance and policy at Classic Teotihuacan. In: Hendon, J.A., Joyce, R.A. (Eds.), Mesoamerican Archaeology: Theory and Practice. Blackwell Publishing, Oxford, pp. 97123.

Sugiyama, S., 2005. Human Sacrifice, Militarism, and Rulership: Materialization of State Ideology at the Feathered Serpent Pyramid, Teotihuacan. Cambridge University Press, Cambridge.

Sugiyama, S., 2011. Interactions between the living and the dead at major monuments in Teotihuacan. In: Fitzsimmons, J.L., Shimada, I. (Eds.), Living with the Dead. Mortuary Ritual in Mesoamerica. The University of Arizona Press, Tucson, pp. 161-202.

Sugiyama, S., Cabrera Castro, R., 2007. The Moon Pyramid Project and the Teotihuacan polity: a brief summary of the 1998-2004 excavations. Ancient Mesoamerica 18, 109-125.

Sullivan, K.S., 2006. Specialized production of San Martín Orange ware at Teotihuacan, Mexico. Latin American Antiquity 17(1), 23-53.

Sullivan, K.S., 2007. Commercialization in Early State Economies: Craft Specialization and Market Exchange in Classic Period Teotihuacan. Ph.D. dissertation, Arizona State University, Tempe.

Swallow, P., Carrington, D., 1995. Limes and lime mortars: part one. Journal of Architectural Conservation 1, 7-25.

Tarlow, S., 2012. The archaeology of emotion and affect. Annual Review of Anthropology 41, 169-185.

Thomas, N., 1991. Entangled Objects: Exchange, Material Culture, and Colonialism in the Pacific. Harvard University Press, Cambridge.

Torrence, R., 1986. Production and Exchange of Stone Tools: Prehistoric Obsidian in the Aegean. Cambridge University Press, Cambridge. 
Tsukamoto, K., Inomata, T. (Eds.), 2014. Mesoamerican Plazas: Arenas of Community and Power. University of Arizona Press, Tucson.

Veblen, T., 1970[1899]. The Theory of the Leisure Class. George Allen and Unwin, London.

Villarreal, M., 2014. Regimes of value in Mexican household financial practices. Current Anthropology 55(S9), S30-S39.

Wattenmaker, P., 1994. Household economy in early state society: Material value, production context and spheres of exchange. In: Brumfiel, E.M. (Ed.), The Economic Anthropology of the State. Monographs in Economic Anthropology, No. 11. University Press of America, Lanham, pp. 93-118.

Weil, J., 2004. Virtual antiquities, consumption values, and the cultural heritage economy in a Costa Rican artisan community. In: Werner, C., Bell, D. (Eds.), Values and Valuables: From the Sacred to the Symbolic. Altamira Press, Walnut Creek, pp. 231-256.

Weiner, A.B., 1992. Inalienable Possessions: The Paradox of Keeping-While-Giving. University of California Press, Berkeley.

Weissner, P., 1983. Style and social interaction in Kalahari San projectile points. American Antiquity 48, 253-276.

Wells, E.C., 2006. Recent trends in theorizing prehispanic Mesoamerican economies. Journal of Archaeological Research 14, 265-312.

Wells, E.C., Davis-Salazar, K.L. (Eds.), 2007a. Mesoamerican Ritual Economy: Archaeological and Ethnological Perspectives. University Press of Colorado, Boulder.

Wells, E.C., Davis-Salazar, K.L., 2007b. Mesoamerican ritual economy: materialization as ritual and economic process. In: Wells, E.C., Davis-Salazar, K.L. (Eds.), Mesoamerican Ritual Economy: Archaeological and Ethnological Perspectives. University Press of Colorado, Boulder, pp. 1-26.

Wenger, E., 1998. Communities of Practice: Learning, Meaning, and Identity. Cambridge University Press, Cambridge.

Werner, C., Bell, D. (Eds.), 2004. Values and Valuables: From the Sacred to the Symbolic. Altamira Press, Walnut Creek.

West, G., 2002. Ceramic exchange in the Late Classic and Postclassic Maya lowlands: A diachronic approach. In: Masson, M.A., Freidel, D.A. (Eds.), Ancient Maya Political Economies. Altamira Press, Walnut Creek, pp. 140-196.

Widmer, R.J., 1987. The evolution of form and function in a Teotihuacan apartment compound. In: McClung de Tapia, E., Rattray, E.C. (Eds.), Teotihuacán: Nuevos datos, nuevas síntesis, 
nuevos problemas. Instituto de Investigaciones Antropológicas, Serie Antropológica 72. Universidad Nacional Autónoma de México, Mexico, D.F., pp. 317-368.

Widmer, R.J., Storey, R., 1993. Social organization and household structure of a Teotihuacan apartment compound: S3W1:33 of the Tlajinga Barrio. In: Santley, R.S., Hirth, K.G. (Eds.), Prehispanic Domestic Units in Western Mesoamerica: Studies in Household, Compound, and Residence. CRC Press, Boca Raton, pp. 87-104.

Wilk, R.R., 2004. Morals and metaphors: the meaning of consumption. In: Ekstrom, K., Brembeck, H. (Eds.), Elusive Consumption. Berg, London, pp. 11-26.

Wilk, R.R., Cliggett, L.C., 2007. Economies and Cultures: Foundations of Economic Anthropology. Second Edition. Westview Press, Boulder.

Wobst, H.M., 1977. Stylistic behavior and information exchange. In: Cleland, C. (Ed.), For the Director: Research Essays in Honor of James B. Griffin. Museum of Anthropology, University of Michigan, Anthropology Paper 61, Ann Arbor, pp. 317-342.

Wolf, E.R., 1990. Distinguished lecture: Facing power - old insights, new questions. American Anthropologist 92, 586-596.

Yoffee, N., 1991. Maya elite interaction: through a glass sideways. In: Culbert, T. (Ed.), Classic Maya Political History: Hieroglyphic and Archaeological Evidence. Cambridge University Press, Cambridge, pp. 285-310.

Yoffee, N., 2005. Myths of the Archaic State: Evolution of the Earliest Cities, States and Civilizations. Cambridge University Press, Cambridge.

Zeitlin, R.N., 1982. Toward a more comprehensive model of interregional commodity distribution: political variables and prehistoric obsidian procurement in Mesoamerica. American Antiquity 47, 260-275. 


\section{List of Tables}

Table 1. List of samples used for this study (QPC: Quetzalpapalotl Palace Complex; SDC: Street of the Dead Complex; WPC: West Plaza Complex; CSS: Complex of Superposed Structures)

\section{List of Figures}

Figure 1. Ceramic chronology of Teotihuacan.

Figure 2. Map of Central Mexico.

Figure 3. The city of Teotihuacan showing the location of architectural complexes mentioned in the text (redrawn with modification after Millon 1973).

Figure 4. A patio unit in the Tetitla apartment compound. Some remnants of original floor and wall lime plaster (with murals) can be seen.

Figure 5. Composition of Group 1 lime plaster (the Miccaotli-Tlamimilolpa phases). Plain polarized (upper) and CL (lower) micrographs of the samples from the Moon Pyramid (A-B: MPF-124) and La Ventilla I (C-D: LVIW-14) (different but overlapping spots were taken with slightly different magnifications). 
Figure 6. Composition of Group 2 lime plaster (the Early Xolalpan phase). Plain polarized (upper) and CL (lower) micrographs of the samples from the Quetzalpapalotl Palace Complex (A-B: QPF-8) and La Ventilla II (C-D: LVIIW-18) (different but overlapping spots were taken with slightly different magnifications).

Figure 7. Plain polarized micrographs of lime plasters from four superimposed walls at $\mathrm{La}$ Ventilla II (A: LVIIW-16; B: LVIIW-17; C: LVIIW-18; D: LVIIW19).

Figure 8. Composition of Group 3 lime plaster (the Late Xolalpan and Metepec phases). Plain polarized (upper) and CL (lower) micrographs of the samples from the main temple of La Ventilla (A-B: LVIW-15; C-D: LVIW-16) (different but overlapping spots were taken with slightly different magnifications). LS represents slightly burnt limestone fragments. LVIW-15 is from an earlier version of the main temple and it is possible that it was built during the Early Xolalpan phase considering the compositional similarity to Type 2 plaster.

Figure 9. Plain polarized (left) and CL (right) micrographs of the samples from Zacuala Palace (A-B: ZacW9), Atetelco (C-D: AtetF2), and Tetitla (E-F: TetF-14) during the Late Xolalpan and Metepec phases (different but overlapping spots were taken with slightly different magnifications).

Figure 10. Location (A) and CL micrographs (B-D) of a lime plaster sample (YayF-2) from the main courtyard of Yayahuala during its final occupation. 


\section{Table 1}

\begin{tabular}{|c|c|c|c|c|c|}
\hline & $\begin{array}{c}\text { Group } 1 \\
\text { (Miccaotli to } \\
\text { Tlamimilolpa) }\end{array}$ & $\begin{array}{c}\text { Group } 2 \\
\text { (Early Xolalpan) }\end{array}$ & $\begin{array}{c}\text { Group } 3 \\
\text { (Late Xolalpan } \\
\text { to Metepec) }\end{array}$ & Unassigned & Total \\
\hline \multicolumn{6}{|l|}{ Central Precinct } \\
\hline Moon Pyramid & 6 & 0 & 0 & 1 & 7 \\
\hline Complex 6:N5W1 & 1 & 1 & 0 & 0 & 2 \\
\hline QPC & 2 & 3 & 4 & 2 & 11 \\
\hline Sun Pyramid & 2 & 1 & 1 & 1 & 5 \\
\hline \multicolumn{6}{|l|}{ SDC } \\
\hline WPC & 2 & 6 & 0 & 0 & 8 \\
\hline CSS & 4 & 0 & 0 & 0 & 4 \\
\hline Ciudadela & 6 & 6 & 5 & 0 & 17 \\
\hline \multicolumn{6}{|c|}{ Intermediate Elite Compounds } \\
\hline La Ventilla I & 5 & 3 & 2 & 0 & 10 \\
\hline La Ventilla II & 3 & 12 & 2 & 0 & 17 \\
\hline Atetelco & 2 & 4 & 3 & 0 & 9 \\
\hline Tetitla & 0 & 6 & 2 & 0 & 8 \\
\hline Zacuala Palace & 0 & 2 & 2 & 0 & 4 \\
\hline Zacuala Patio & 0 & 2 & 2 & 0 & 4 \\
\hline Yayahuala & 0 & 2 & 4 & 0 & 6 \\
\hline Tepantitla & 0 & 2 & 1 & 0 & 3 \\
\hline \multicolumn{6}{|c|}{ Commoner's Compounds } \\
\hline La Ventilla III & 1 & 3 & 1 & 0 & 5 \\
\hline Total & 34 & 53 & 29 & 4 & 120 \\
\hline
\end{tabular}


Figure 1

\begin{tabular}{|c|c|c|}
\hline \multirow{5}{*}{ 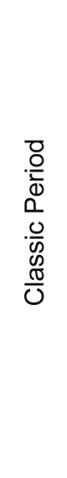 } & 600 & Metepec \\
\hline & \multirow{2}{*}{$\begin{array}{l}500 \\
400\end{array}$} & Late Xolalpan \\
\hline & & Early Xolalpan \\
\hline & \multirow{2}{*}{300} & Late Tlamimilolpa \\
\hline & & Early Tlamimilolpa \\
\hline \multirow{3}{*}{ 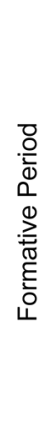 } & 200 & Miccaotli \\
\hline & 100 & Tzacualli \\
\hline & 100 & Patlachique \\
\hline
\end{tabular}




\section{Figure 2}

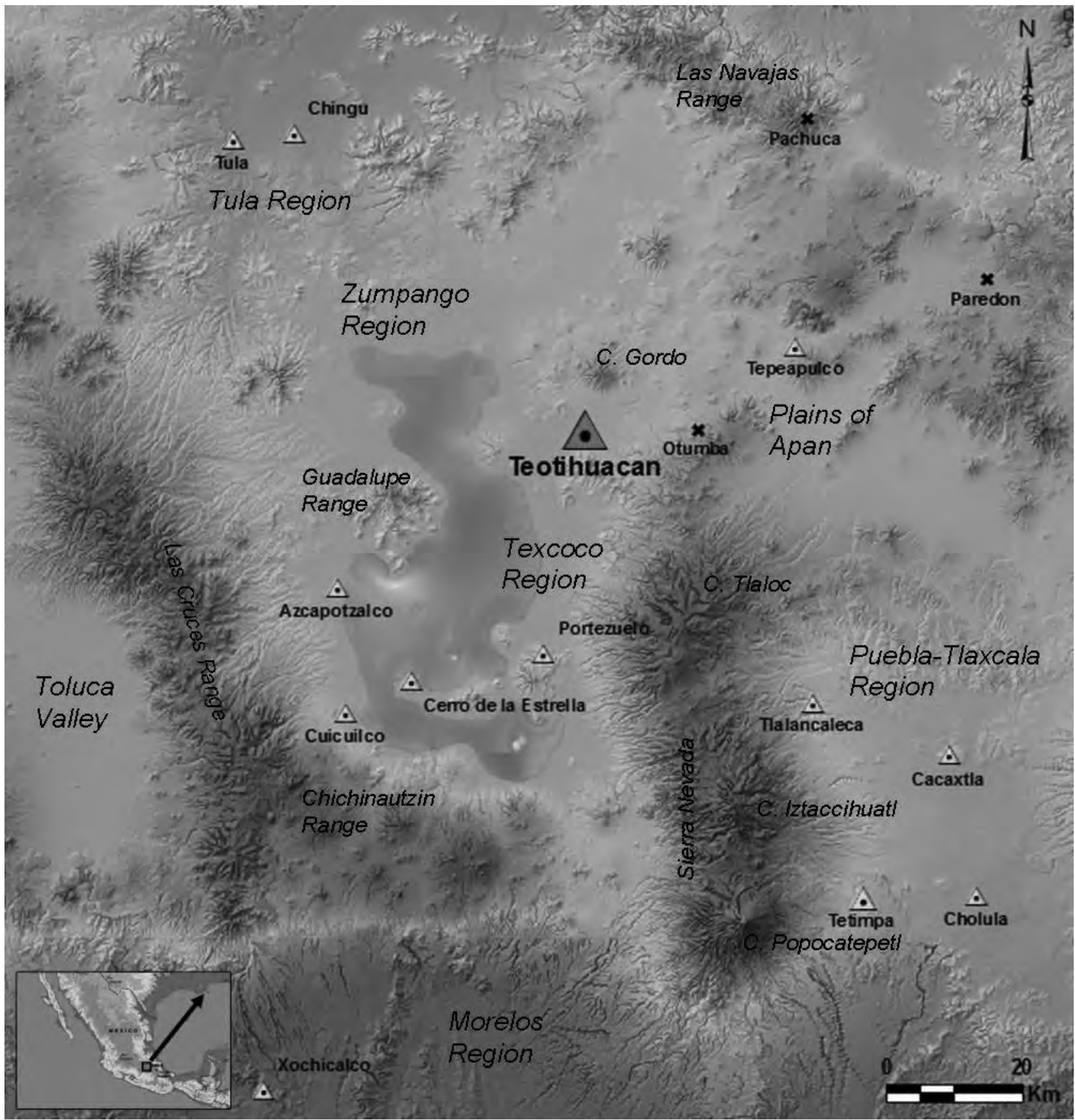


Figure 3

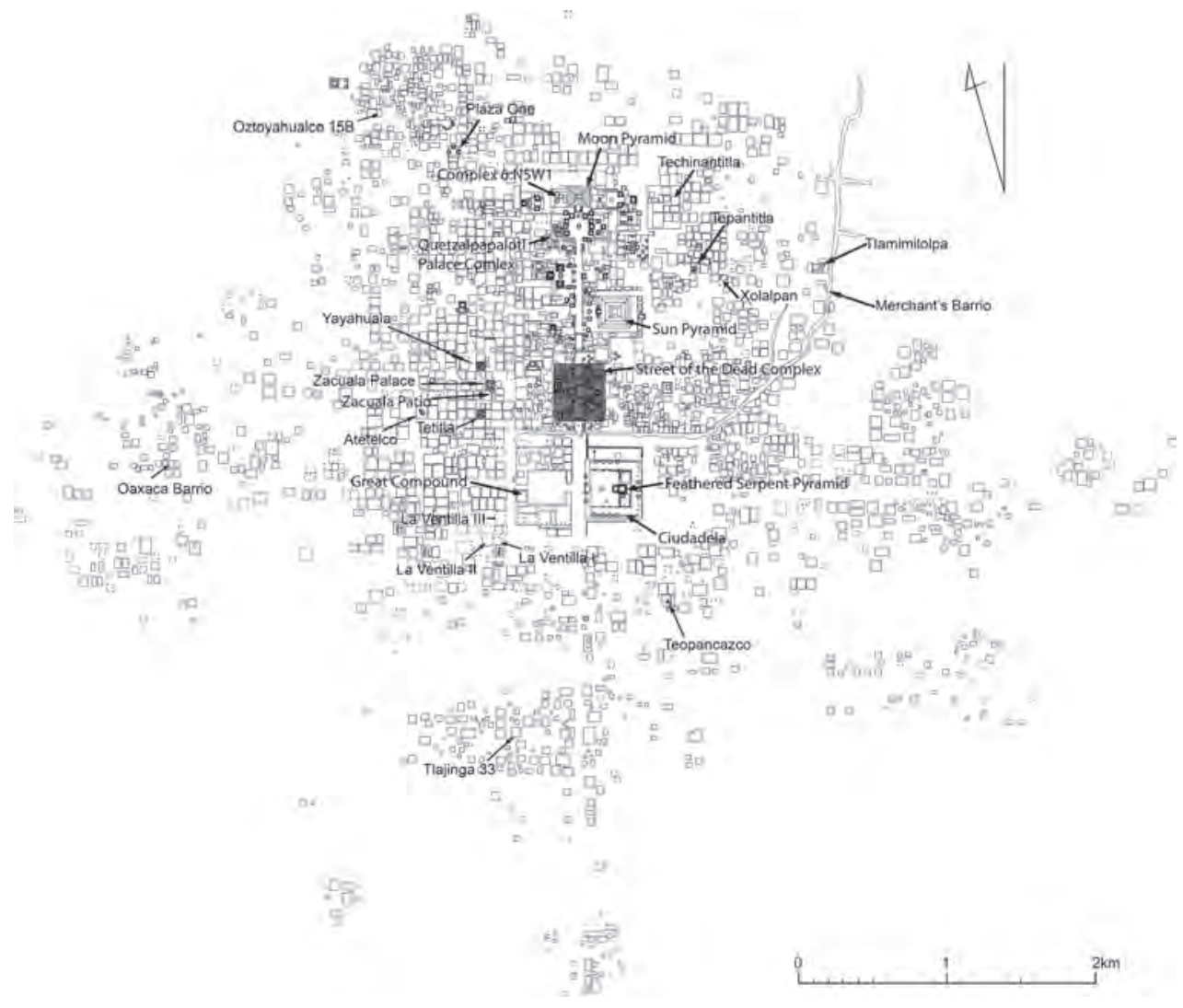


Figure 4

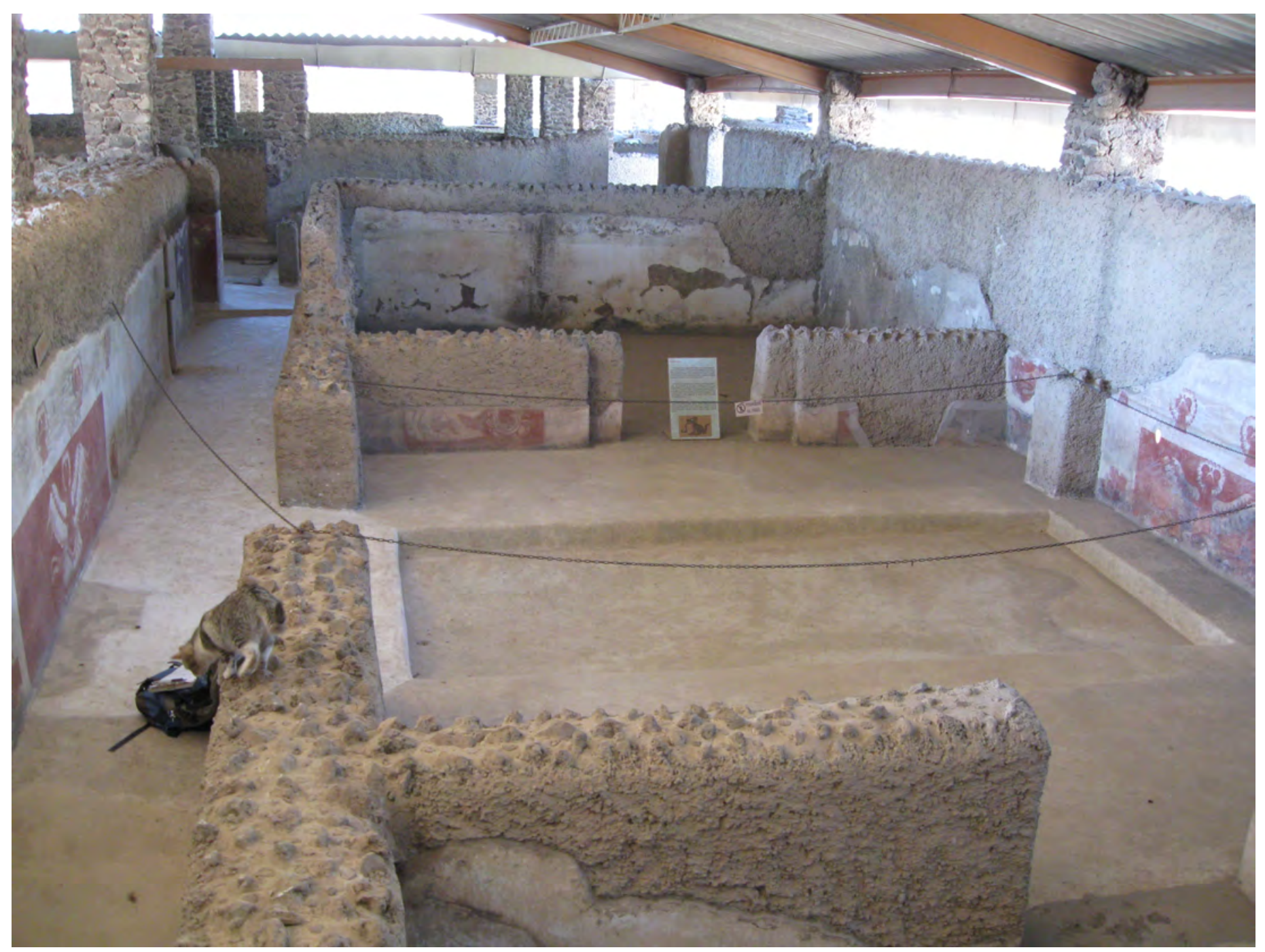


Figure 5
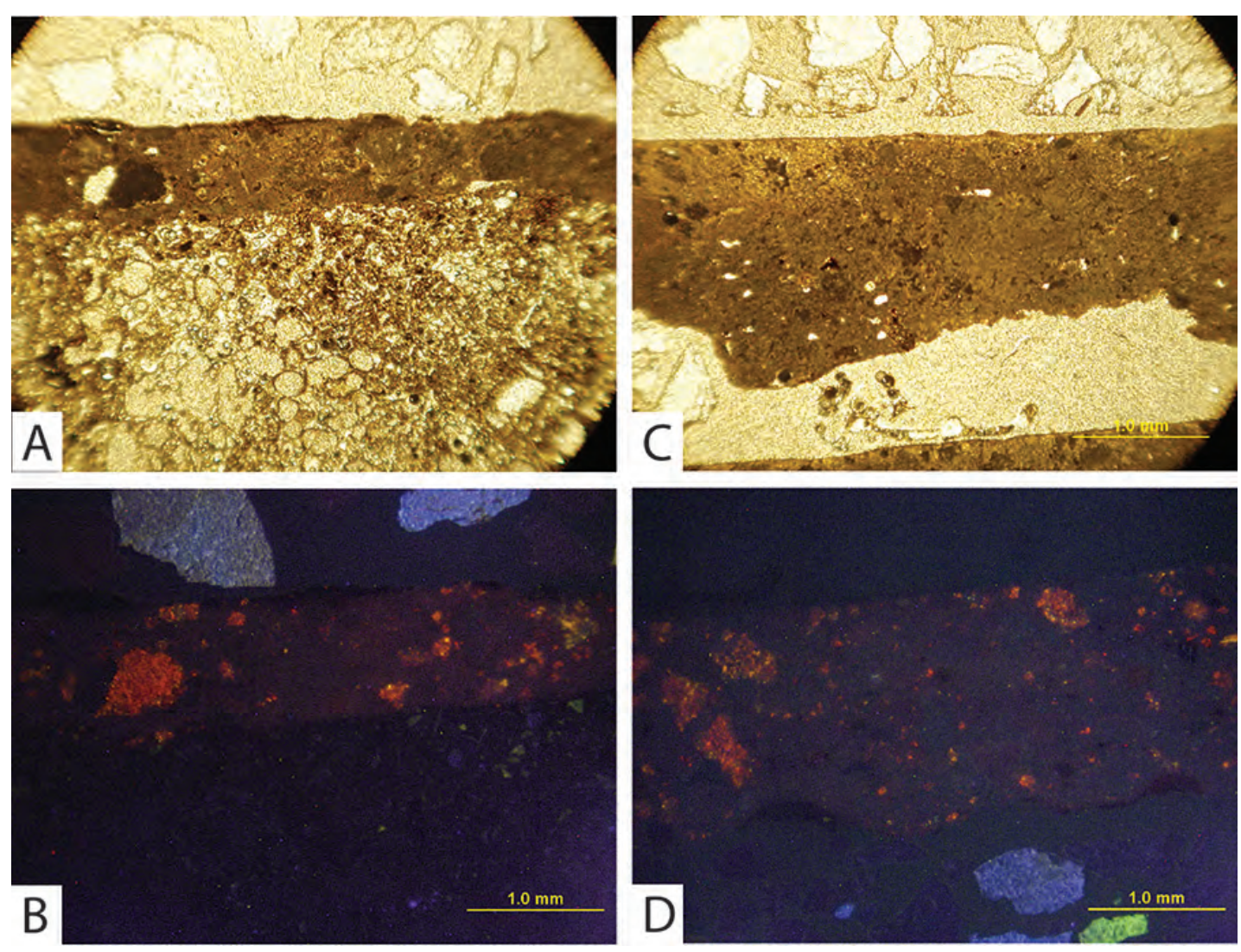
Figure 6
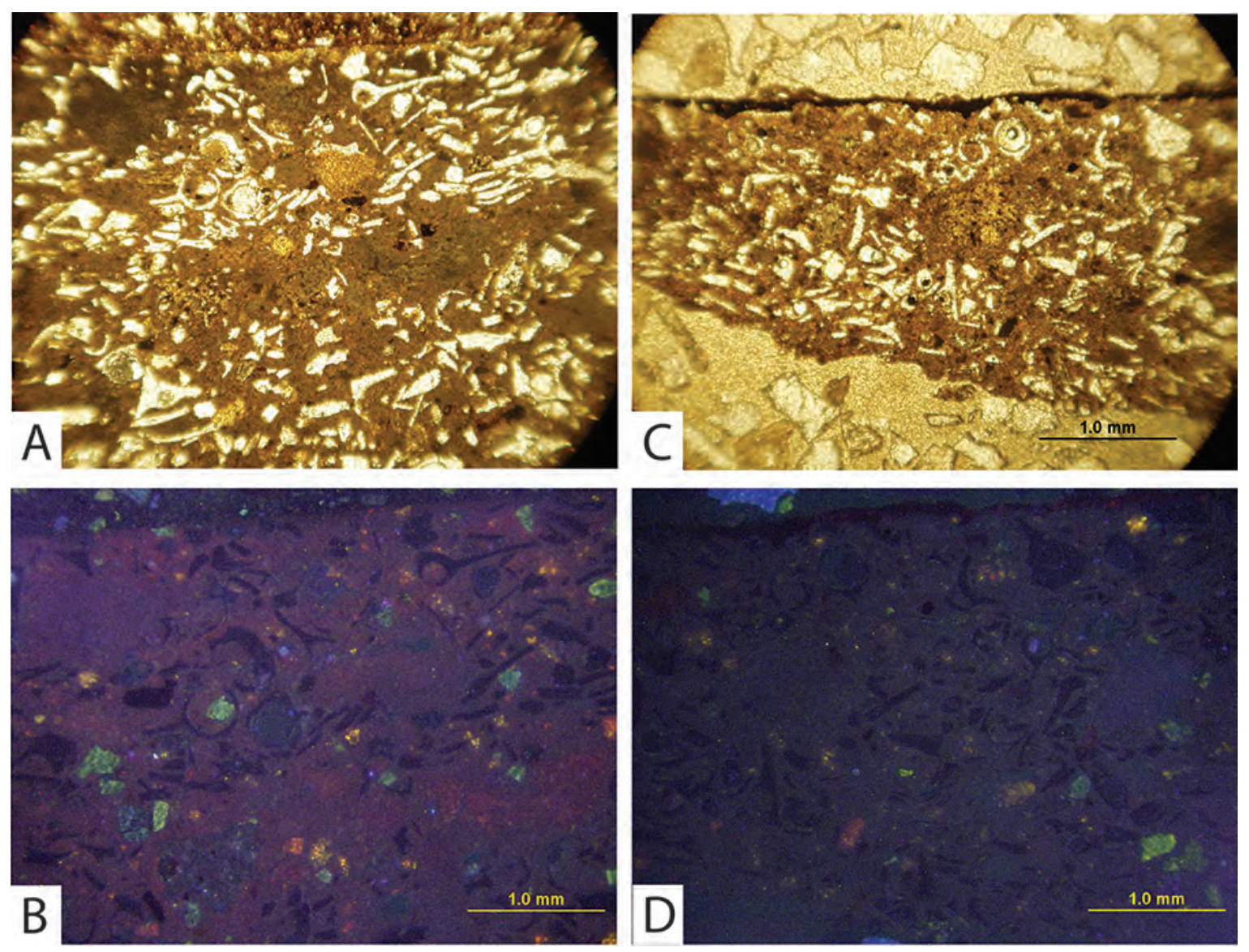
Figure 7

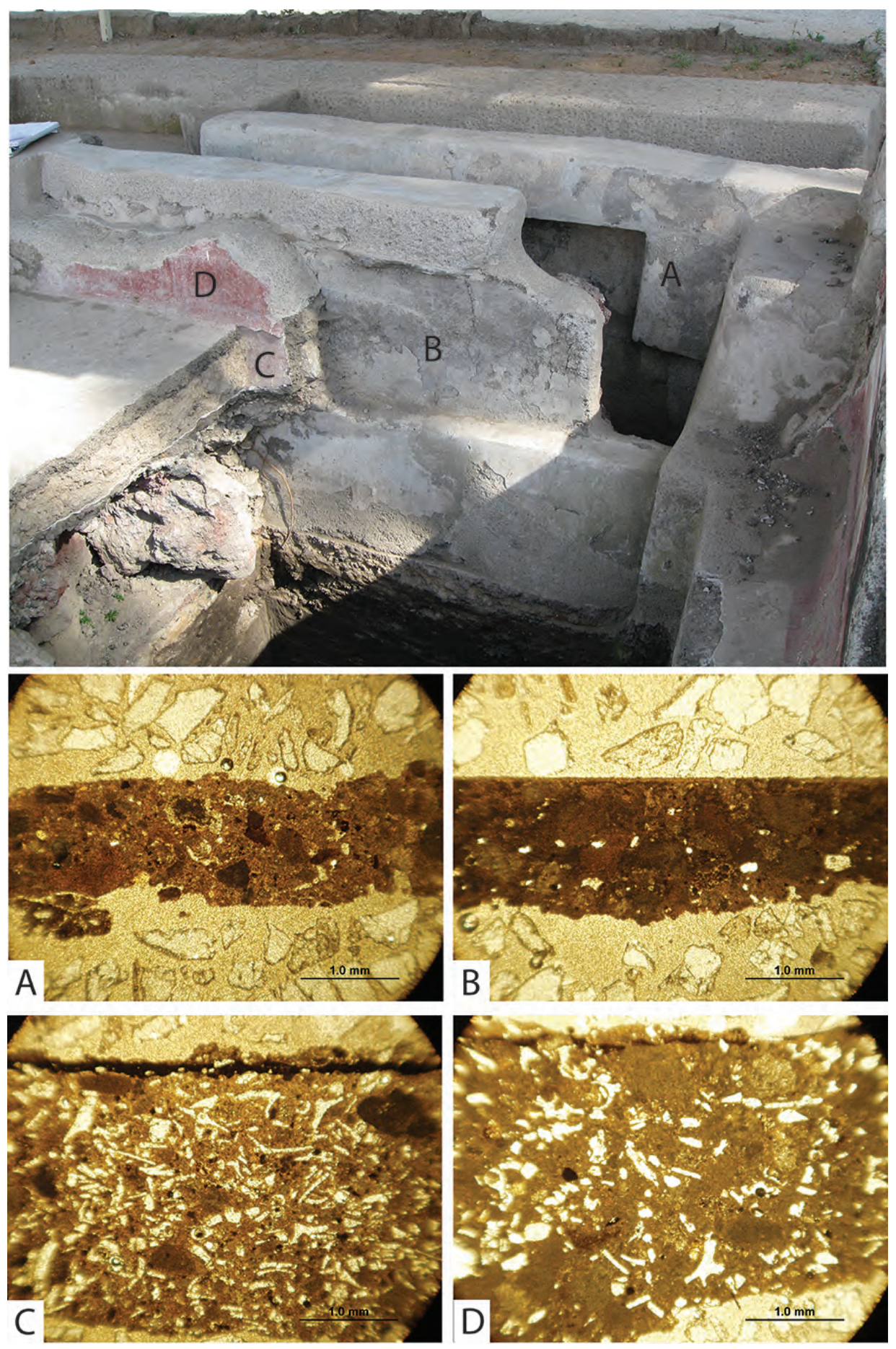




\section{Figure 8}
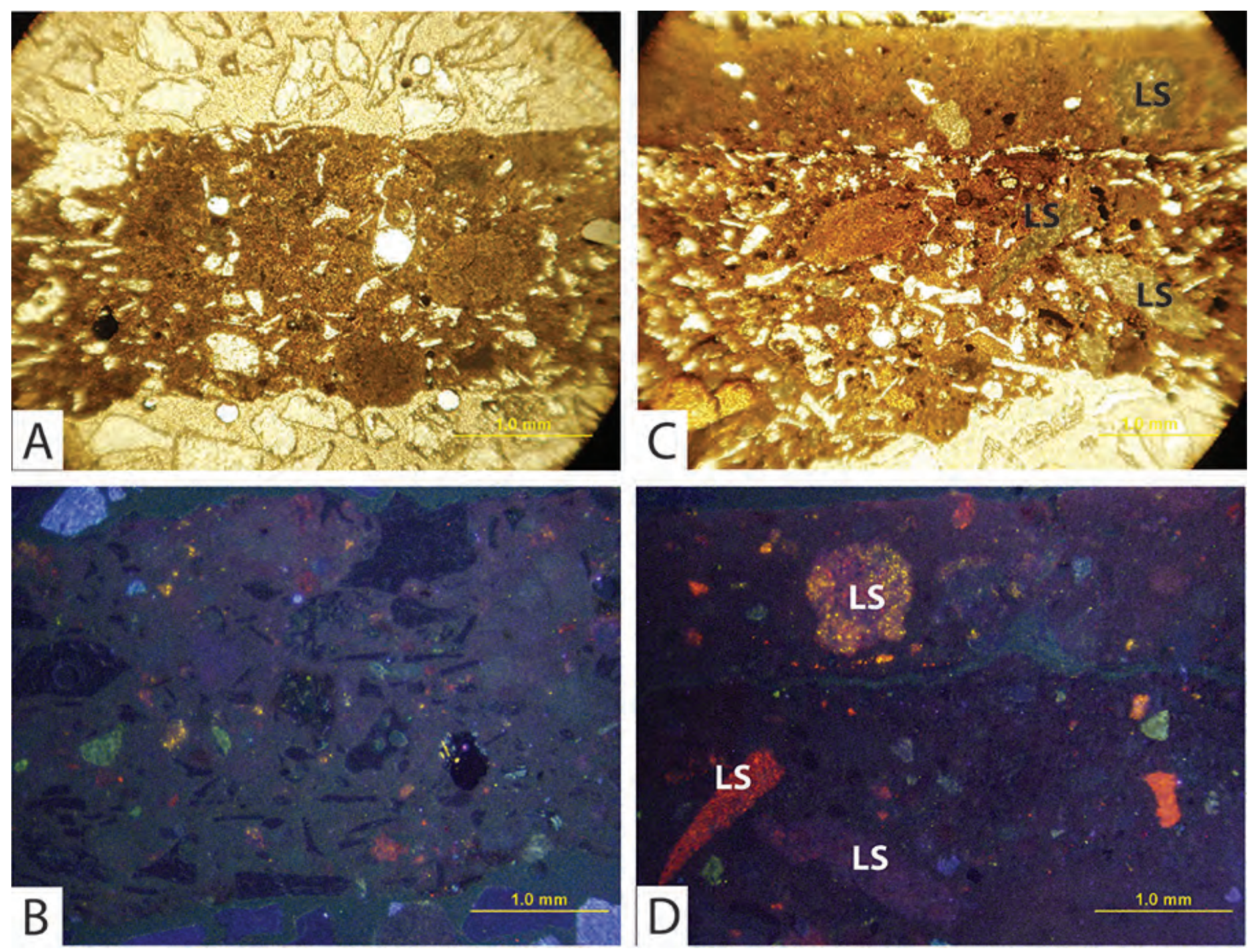
Figure 9
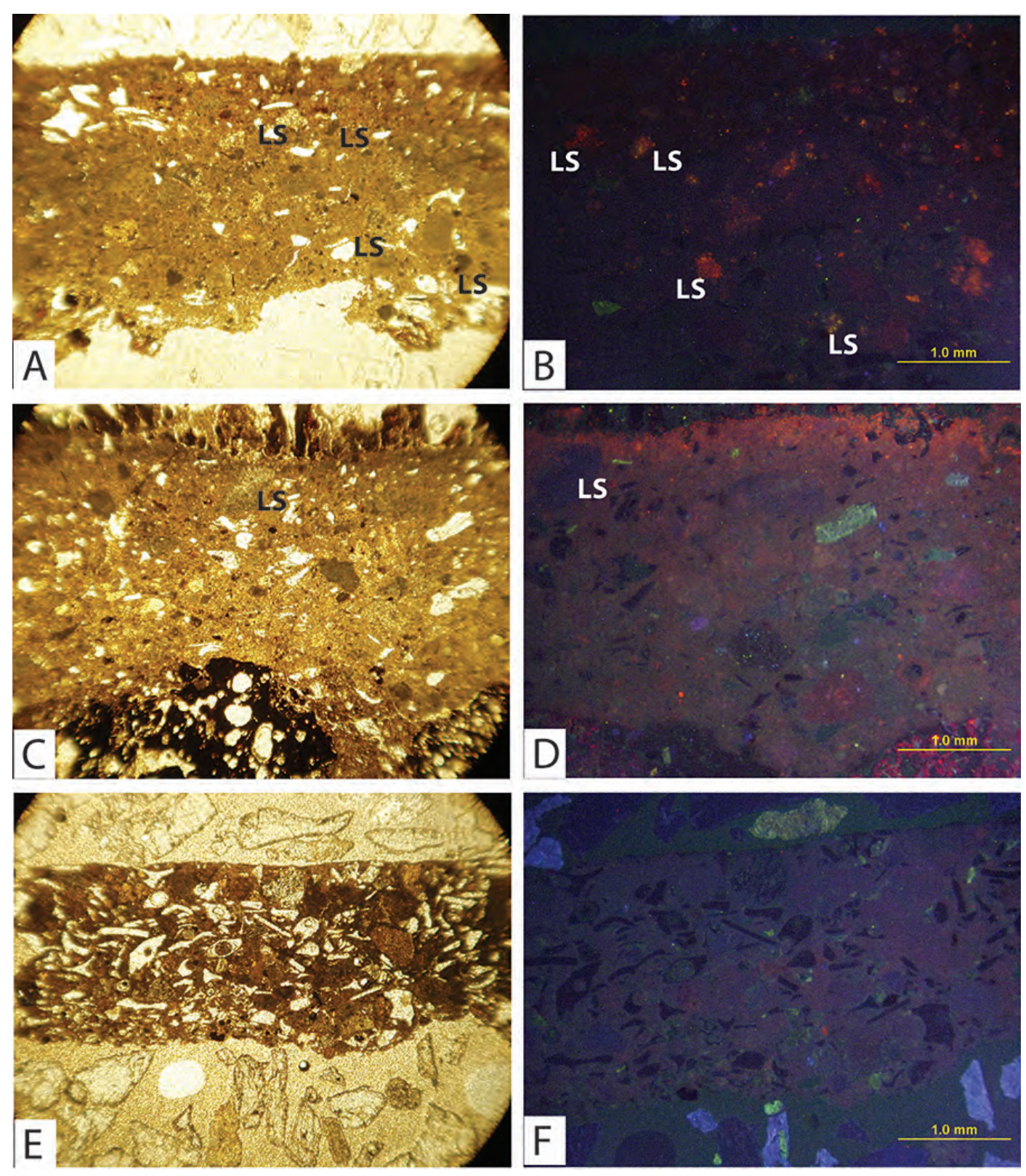
Figure 10
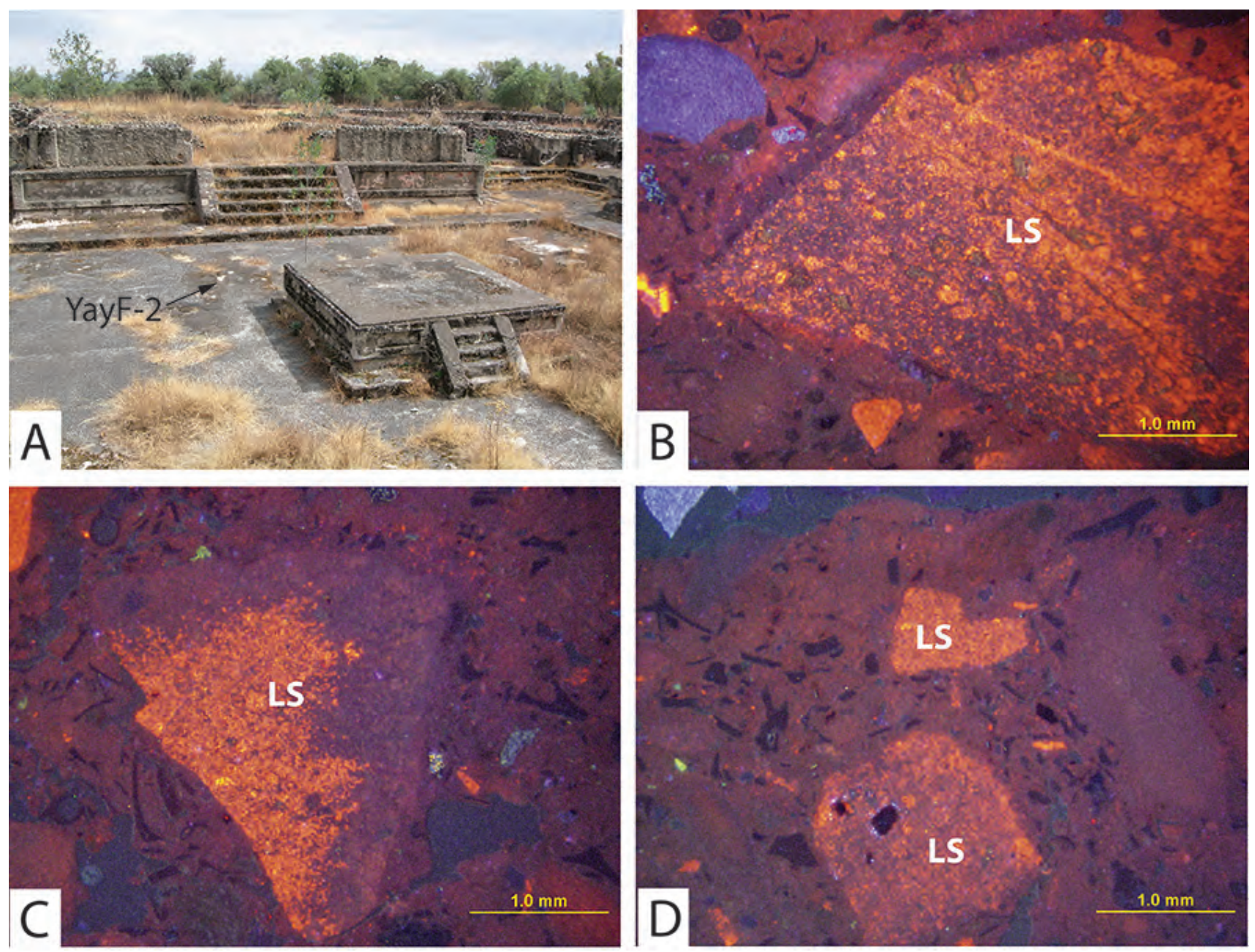